\title{
Localized learning by emerging multinational enterprises in developed host countries: A fuzzy-set analysis of Chinese foreign direct investment in Australia
}

\author{
Di Fan ${ }^{\mathrm{a}, 1}$, Lin Cui ${ }^{\mathrm{b}, *}$, Yi Li ${ }^{\mathrm{b}, 2}$, Cherrie J. Zhu ${ }^{\mathrm{c}, 3}$ \\ a Deakin Graduate School of Business, Deakin University, Melbourne, Australia \\ ${ }^{\mathrm{b}}$ College of Business and Economics, Australian National University, Canberra, Australia \\ ${ }^{\mathrm{c}}$ Department of Management, Monash University, Melbourne, Australia
}

\section{A R T I C L E I N F O}

Article history:

Available online $\mathrm{xxx}$

\section{Keywords:}

Dynamic capability

Foreign direct investment

Fuzzy-set analysis

Internationalization process

Localized learning

\begin{abstract}
A B S T R A C T
Firms learn general international management and foreign market specific knowledge in their internationalization process. Firms' strategic emphasis on generalized vs. localized learning is an important yet underexplored issue in the extant literature. Drawing on the theoretical framework of dynamic capability, and in the context of emerging multinational enterprises' FDI into developed host countries, this study examines the equifinal process-position-path configurations of firms that will motivate them to engage in localized learning (as opposed to generalized learning). Utilizing primary and secondary data of eleven Chinese foreign direct investments in Australia, collected at both headquarters and subsidiary levels, we conducted fuzzy-set qualitative comparative analysis (fsQCA) that provided substantial support to our propositions. This study contributes to the internationalization process model by identifying equifinal process-position-path configurations, as well as their core and peripheral conditions that motivate localized learning at both the headquarters and the subsidiary levels.
\end{abstract}

(c) 2015 Elsevier Ltd. All rights reserved.

\section{Introduction}

The internationalization process model (IPM) highlights the role of knowledge, and hence the process of learning, in firms' international strategy formulation and implementation (Johanson \& Vahlne, 1977; Johanson \& Vahlne, 1990). It focuses on experiential learning, through which firms acquire general knowledge of international management as well as localized knowledge related to specific foreign markets (Eriksson, Johanson, Majkgard, \& Sharma, 1997). The learning of such general and localized knowledge influences further internationalization of the firm (Chan \& Makino, 2007; Chang, 1995). Specifically, general knowledge of international management allows firms to replicate successful practices in foreign locations and achieve global integration, while localized knowledge enables firms to benefit from different location advantages of foreign markets and achieve

\footnotetext{
* Corresponding author. Tel.: +6126125 6190

E-mail addresses: david.fan@deakin.edu.au (D. Fan), lin.cui@anu.edu.au (L. Cui), yi.li@anu.edu.au (Y. Li), cherrie.zhu@monash.edu (C.J. Zhu).

1 Tel.: +6139244 6985

2 Tel.: +6126125 7278.

${ }^{3}$ Tel.: +61399055465
}

local responsiveness (Bartlett \& Ghoshal, 1998). Despite the important and diverging strategic implications of generalized vs. localized learning, we know little about what influences firms' motivation to emphasize one type of learning over the other. This knowledge gap limits our understanding of firm's internationalization process, especially that of emerging multinational enterprises (EMNEs), where localized (as opposed to generalized) learning, namely the learning of localized knowledge, is asserted to serve the strategic intents of these latecomers to catch up with their developed country counterparts (Cui, Meyer, \& Hu, 2014; Liu \& Buck, 2009; Rui \& Yip, 2008).

Recent studies of EMNEs suggest that these "late-comer" firms actively utilize FDI as a channel to acquire overseas advanced knowledge to enhance their global competitiveness (Cui et al., 2014; Rui \& Yip, 2008). Unlike established multinational enterprises that exploit existing ownership advantage through global standardization strategy, EMNEs need to engage in localized learning, especially in their FDI into developed host countries, to acquire foreign strategic assets and redress their ownership disadvantages. In the context of EMNEs' FDI, learning is usually localized in overseas settings (Luo \& Peng, 1999), and first occurs at the business level (i.e., subsidiaries) before transferring back to the corporate level (Erramilli, 1991). As such, localized learning is an 
important mechanism affecting the internationalization success of EMNEs. However, the current literature lacks a theoretical explanation of firms' learning emphasis in their internationalization process. This study addresses this gap by answering the following research question: What motivates EMNEs to engage in localized learning in developed host countries?

We follow a configurational approach of theory building that has been increasingly adopted in organizational research (Fiss, 2007,2011 ). In contrast to a contingency approach, which aims to identify the causal condition that maximizes the desired outcome, the configurational approach allows for equifinality and explores multiple causal pathways that can lead to the same level of the desired outcome. We adopt the configurational approach because the core of the research question, localized learning, is a means to an end. As localized learning can serve different strategic intents, such as acquiring technology, expanding markets, or developing human resources (Cui et al., 2014; Luo \& Tung, 2007), firms' motivation to engage in localized learning may vary. Therefore, there is no set formula to maximize the motivation of localized learning, rather, there can be multiple configurations of firm internal and external factors that lead to the same learning emphasis of firms. This configurational approach can be implemented through a fuzzy-set qualitative comparative analysis (fsQCA) which allows us to explore the equifinal motivating conditions of localized learning (Crilly, 2011; Fiss, 2007, 2011).

We draw on a dynamic capability framework to identify the individual factors that are relevant to firms' motivation of engaging in localized learning. Dynamic capabilities refer to a firm's ability to integrate, build, and reconfigure internal and external competences to address rapidly changing environments (Barreto, 2010; Teece, Pisano, \& Shuen, 1997), which are necessary to sustain superior enterprise performance, especially in fast-moving global environments (Zhou, Barnes, \& Lu, 2010). Teece (2014) promotes a capabilities-based theory of the multinational enterprises, which explains how firms maintain and develop their competitive advantages in unfamiliar and changing environments during the internationalization process. While localized learning can serve various strategic intents of EMNEs, all these intents are related to building dynamic capabilities by integrating, building, and reconfiguring firm' internal and host country external competences. Also, compared with other dominant frameworks in the international business literature, notably the transaction cost framework, a capabilities-based framework is more relevant for the internationalization of EMNEs, which are relatively less concerned about economizing on existing competences but more focussed on developing new ones. Thus, the dynamic capability framework serves as an ideal guiding framework for this study. Specifically, Teece et al. (1997) identify three building blocks of dynamic capabilities; processes, positions and paths. In the context of localized learning, we identify relevant factors that fall under these three building blocks, and then subject them to fsQCA to explore the potential process-position-path configurations that lead to localized learning.

Empirically, we choose the context of Chinese FDI in Australia. Compared to EMNEs from other home countries, the phenomenon of Chinese FDI has attracted academic attention. Prior studies suggest that Chinese firms are proactive and entrepreneurial in terms of building dynamic capabilities overseas (Cui et al., 2014; Lyles, Li, \& Yan, 2014; Zhou et al., 2010). We choose Australia as the focal host country, not only because it is a primary destination of Chinese FDI, where Chinese firms engage in a wide range of industries in resources, manufacturing and services for knowledge seeking and market seeking purposes (FIRB, 2012; KPMG, 2013), but also that the relatively isolated geo-economics of Australia provides an ideal "natural lab" for Chinese firms to experiment with entrepreneurial activities for capability building. While
Australia resembles major developed markets (such as the US and Europe) in terms of institutions, market segmentation, and culture, its relatively small and isolated economy enables quicker market feedback and lower-cost experimentation. As a result, many Chinese firms use Australia as a test-ground for global capability building before entering the major triad markets (Fan, Zhu, \& Nyland, 2012; Zhang \& Fan, 2014). Moreover, the investment environment in Australia is fast changing, especially for Chinese FDI, given the increasing reliance of Australia on Chinese investment and the intensifying political and social debate leading to unpredictable and frequent policy changes. Such an environment requires Chinese firms to constantly upgrade their dynamic capabilities through localized learning to adapt to new market trends, policy requirements, and competence-enhancing opportunities (cf. Fan, Zhang, \& Zhu, 2013; Nyland, Forbes-Mewett, \& Thomson, 2011).

The study utilizes qualitative data, such as interviews with 22 senior executives and archives, collected from both headquarters and Australian subsidiary levels of nine Chinese MNEs in their 11 FDI projects in Australia. The next section provides a literature review covering the six causal conditions derived from the process-position-path framework. Three propositions are then derived drawing on both dynamic capability and configurational theoretical perspectives and the research design is explained. The empirical results are then detailed, the implications of the findings are analyzed and a future research agenda is proposed.

\section{Theoretical framework}

We adopt a dynamic capability framework as a guiding theoretical framework to identify the elements of potential configurations leading to localized learning. Teece (2014) proposes a capabilities-based theory of MNE which focuses on learning and knowledge issues in international business rather than transaction cost issues. This framework is particularly relevant to the internationalization of EMNEs. Luo (2001) argues that localized learning reflects a firm's dynamic learning capability, which measures how MNEs learn to identify fit, with specific environmental and resource contingencies within a host economy, or across different host country contexts (Gupta \& Govindarajan, 1991). Localized learning is particularly associated with the dynamic capabilities of EMNEs investing in developed host countries. EMNEs actively invest in developed host countries to access key assets, resources and technologies (Morck, Yeung, \& Zhao, 2008; Ramamurti \& Singh, 2009). By localizing their learning efforts in such host countries, EMNEs set up their subsidiaries as conduits to fulfil their competence-building strategic intents (Cui et al., 2014).

Teece et al. (1997) identify three building blocks of dynamic capabilities; processes, positions and paths. We argue that the configurations of the factors associated with these building blocks motivate firms to engage in localized learning. Guided by these three building blocks, we identify factors relevant to the context of FDI. A conceptual framework is depicted in Fig. 1, which shows (1) theoretical constructs of observable antecedent and outcome variables in squared boxes, (2) set-theoretical causal mechanisms in circles, and (3) corresponding propositions pertaining to the linkages between constructs and causal mechanisms.

\subsection{Processes}

Organizational processes embed the strategy and business model into internal norms and routines. The input-process-output model also highlights the important mediation of processes in businesses (Miles, Snow, Meyer, \& Coleman, 1978; West \& Anderson, 1996). The implementation of strategic behaviour, such as localized learning, necessarily depends on the existing culture 


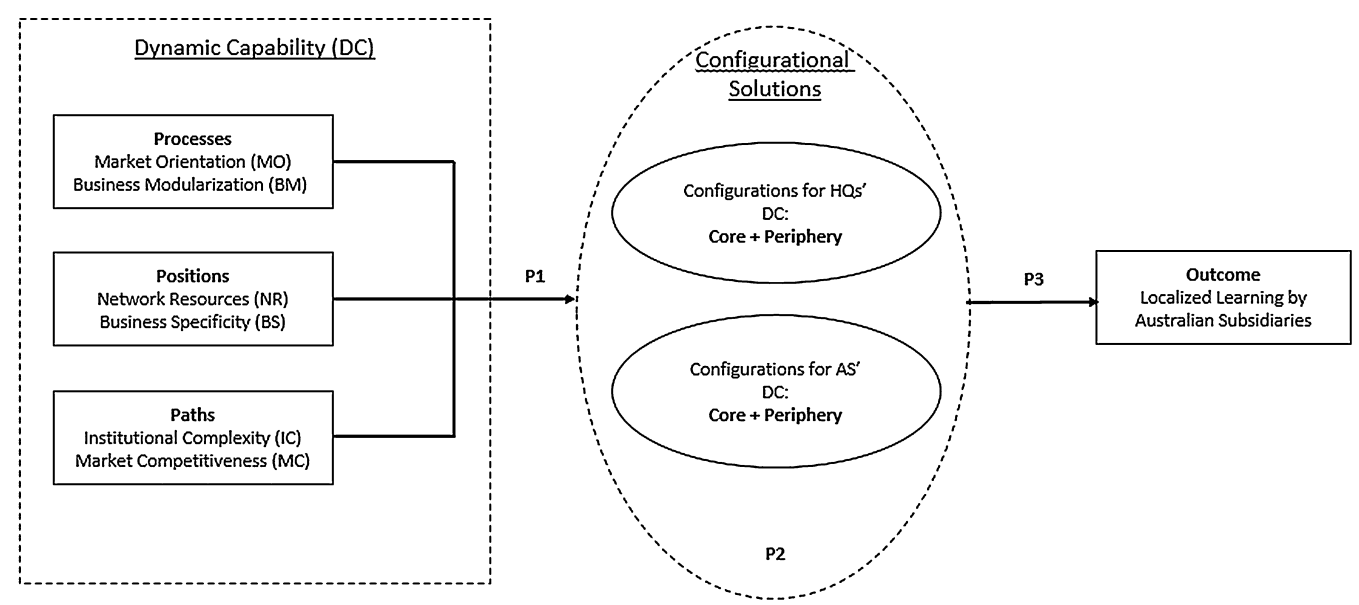

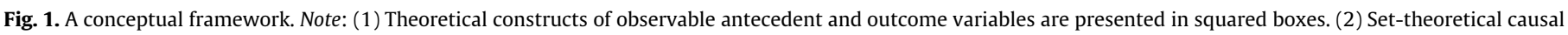
mechanisms are presented in circles.

and routines in the organization, because the very purpose of localized learning (and dynamic capabilities in general) is to design, develop, implement, and modify these internal norms and routines (Teece et al., 1997). In the context of FDI, the internal norm of market orientation and the operational routine of modularization have important implications on localized learning.

\subsubsection{Market orientation (MO)}

Market orientation is defined as the "organizational culture that most effectively and efficiently creates the necessary behaviours for the creation of superior value for buyers and thus continues superior performance for the business" (Narver \& Slater, 1990: 21). A market orientation provides strong norms for learning from customers and competitors, which can benefit any business that is willing to maximize organizational learning on creating superior customer value in dynamic and turbulent markets, because the ability to learn faster than competitors is one of major sources of sustainable competitive advantage (Ichijo \& Kohlbacher, 2008; Slater \& Narver, 1995). Luo (2001) suggests that an export market orientation involves a low level of a subsidiary's learning capability, whereas a host market orientation is associated with more effort dedicated to localized learning. Empirical research has supported this argument (Grein, Craig, \& Takada, 2001; Taggart, 1997).

\subsubsection{Business modularization (BM)}

Initially introduced by Starr (1965), business modularization implies a product design approach whereby the product is assembled from a set of standardized constituent units. MNEs are faced with the choice of importing or localizing supplies when they establish manufacturing subsidiaries overseas (Eberhardt, McLaren, Millington, \& Wilkinson, 2004). By bridging the advantages of standardization and rationalization with customization and flexibility, the concept is extended here to refer to a "localized" choice through using the basic principle of "substitutability" between generic models that the firm has successfully generated from prior operations, such as headquarters and/or other sister subsidiaries (cf. Ernst \& Kamrad, 2000). The localized choice is one, or several components of a product, or parts or percentages of a product manufactured by an MNE that must be supplied by local firms in the host country. Although there are academic debates on the benefits (such as, cost saving, the availability of desired quality expectation and the attraction of local customers) and problems (e.g., pressure to MNEs' subsidiaries, and increase local supplier's bargaining power) of an MNEs' decisions of business modularization, it is commonly agreed that the localized choice of supplies directly and strongly drives up
MNE localized learning efforts (cf. Boddewyn \& Brewer, 1994; Eberhardt et al., 2004; Swamidass \& Kotabe, 1993).

\subsection{Positions}

The building block of "positions" in a dynamic capability framework refers specifically to the resource/assets position of the firm (Teece, 2014), which originates from the resource-based view of firms (Barney, 1991). According to Barney (1991), firm-specific resources form the foundation for competitive advantages. Teece et al. (1997) extend that the dynamic capabilities to reconfigure a firm's resources are critical to the sustainability of competitive advantage. Beyond the balance sheet assets (such as plant and equipment) which are more related to ordinary capabilities of firms (Drnevich \& Kriauciunas, 2011), Teece (2014) emphasizes relational/institutional and technological assets for the development of dynamic capabilities. Such assets are also found to have significant value for the success of FDIs (Elango \& Pattnaik, 2007; Lin, Cheng, \& Liu, 2009; Meyer, Wright, \& Pruthi, 2009).

\subsubsection{Network resources (NR)}

Granovetter (1995) and Luo (2002) have identified that many countries have a long tradition of doing business based on interpersonal relationships with executives in partnership, suppliers, buyers, distributors, competitor firms and governmental authorities. Established networks refer to an MNE's network of coalition-based stakeholders sharing resources for survival, and also for achieving business success in host countries. Among all relations in the established network, relations with local governments or seeking local government support are most critical, based on previous studies (Jarillo \& Martinez, 1990; Su, Mitchell, \& Sirgy, 2007). As a source of relational capital, managerial ties with other local firms, communities and governments play important roles in countering external threats and compensating for resource deficiencies (Luo, 2001, 2002). Having established a network with host countries, MNEs can enhance localized learning because they will seek benefits from their already committed social capital (Burt, 1997; Gao, Liu, \& Zou, 2013). Likewise, Zhang and Fan (2014) observe that established social networks in host countries, such as associations of Chinese MNEs, associations of hometown colleagues, and circles of friends, contribute a great deal to the crosscultural learning and adjustment of Chinese expatriates.

\subsubsection{Business specificity (BS)}

Business specificity concerns the nature of the knowledge contents and know-how of business. Highly specific knowledge 
and know-how are subject to potentially high transaction costs if exposed to market transaction (Anderson \& Coughlan, 1987; Meyer et al., 2009). As localized learning necessarily involves frequent contact and information exchange with business partners in the host country, the transaction hazard for highly specific knowledge and know-how is expected to be high. Therefore, there is a need to constantly re-evaluate and upgrade firm-specific knowledge and know-how to maintain local competitiveness (Luo, 2001). Tallman (1991) argues that localized learning is necessary and essential for the successful foreign operation with high levels of business specificity because localized learning enables the investing firm to capitalize on its specific capability advantages and thus differentiate its performance against competitors (Collis, 1991).

\subsection{Paths}

The third building block of dynamic capability, path, refers to the orchestration and implementation of business strategies to shape the path ahead (Teece, 2014). Strategy determines product scope, market target, and competitive actions, based on prescient diagnoses of the competitive environment the firm is situated in. While there is no best strategy generally applicable to all firms, the best strategy for a specific firm can be formed through a process of trial and error in its operating environment. In other words, firms' perceptions and diagnoses of environment influence their strategic choices leading to their future paths. The FDI literature highlights the challenges in foreign institutional and market environments where the investing firm faces the liability of foreignness ( $\mathrm{Xu} \&$ Shenkar, 2002; Zaheer, 2002), which can be overcome by learning local practices (Zaheer, 1995).

\subsubsection{Institutional complexity (IC)}

Host country environment complexity has potential impacts on MNE subsidiary's learning capability (Boisot \& Child, 1999; Ghoshal, 1987; Li, Li, Liu, \& Wang, 2005; Prahalad, 1975; Root, 1988). Root (1988) asserts that uncertainty and risks embodied within the complex environment are usually beyond the control of the firm. Other common views are that as environmental complexity grows, the transaction costs of operating business overseas may increase (Prahalad, 1975; Dunning, 1981); and the adaptability of subsidiaries needs to improve in order to reduce the liability of foreignness and enhance the evolutionary development of sustainable advantages (Collis, 1991).

\subsubsection{Market competition (MC)}

Local market competition concerns the competition intensity in the host country market, that is, the rivalry between an MNE's subsidiary and other businesses striving for the same customers or market. Porter (1990) claims that when the degree of competition in a host country is high, a foreign MNE needs to be more responsive to customer needs and provide better products and superior services. Luo (2001: 458) further suggests that "even if a company uses product differentiation or a strategic focus strategy in response to increasing competition, it still must develop innovations to meet the utility functions of various consumers in a segmented market". Hence, highly localized learning is strongly required. Empirical studies (Jarillo \& Martinez, 1990; Luo, 2001; Taggart, 1997) show that high levels of subsidiary learning capability are denoted as a consequence of the complex competition in the local market.

\section{Research propositions}

Six factors representing the three building blocks of dynamic capabilities are identified above as the potential elements of the causal configurations of localized learning. Following the configurational approach of theory building (Crilly, 2011; Fiss, 2007, 2011), we propose that, rather than the independent effects of the identified factors, configurations of these factors are what drive EMNEs to engage in localized learning. Such a configurational approach has not been employed in prior studies of EMNEs internationalization strategy. Hence the current study is of an exploratory nature mimicking mid-range theory building. We offer three research propositions following (Fiss, 2011) to guide the exploratory process facilitated by fsQCA technique.

\subsection{Configurations as causal effects}

A desired outcome can be achieved by multiple configurations of causal conditions. The strategic management literature is currently dominated by a contingency approach which focuses on the optimal interaction of causal factors. The notion of optimal solution is objected by the configurational approach, which suggests that multiple causal pathways can exist to achieve the desired outcome. Doty and Glick (1994) argue that offering configurations can be used to predict variance in an outcome of interest, which plays a key role in disclosing the cause-effect relationships, and centres on understanding and communicating with strategic management scholars and managers in organizations. In line with Birkinshaw and Morrison (1995), this study takes a configurational approach to factors affecting localized learning. According to Miller (1986: 236), configurations are "tight constellations of mutually supportive elements", the implication being that certain structural arrangements may be more appropriate to strategic decision makers. The approach has been used in many areas of organization and management research (e.g., Fiss, 2007; Meyer, Tsui, \& Hinings, 1993) but of greater relevance here is a substantial body of work in strategic management that has applied the configuration approach specifically to business level strategy (e.g., Birkinshaw \& Morrison, 1995; Fiss, 2007, 2011; Miller, 1986). As localized learning is a strategic behaviour of particular importance for the internationalization success of EMNEs from a dynamic capability perspective, we argue that it is likely to be motivated by a nexus of process-positionpath factors working in configurations rather than isolation. Hence, we propose:

Proposition 1. Configurations of process, position, and path conditions will motivate EMNEs to engage in localized learning in developed host countries.

\subsection{Asymmetry in causal configurations}

Causal configurations are often featured with conditions of unequal importance to the outcome. Drawing on arguments from the strategy and organizational design literatures (e.g., Grandori \& Furnari, 2008; Siggelkow, 2002), Fiss (2011) argues that strategic configurations frequently consist of a 'core' and a 'periphery', with the core elements being essential and the peripheral elements being less important and perhaps even expendable or exchangeable. Fiss (2011: 394) develops a definition of 'coreness' based on causal connection to the outcome of interest, arguing that "core elements are those causal conditions for which the evidence indicates a strong causal relationship with the outcome of interest and peripheral elements are those for which the evidence for a causal relationship with the outcome is weaker." The notion of causal core and periphery extends prior thinking on cause-effect relationships by implying 'causal asymmetry' (Ragin, 2008). Prior studies suggest that the notion of distinguishing core and peripheral concepts is important with regard to causal inferences and may "draw a decision marker's attention to non-existent relationships because managers tend to automatically infer new 
events by the use of core concepts" (Barr, Stimpert, \& Huff, 1992: Fiss, 2011: 397; Nadkarni \& Narayanan, 2007). As localized learning is an important strategic decision for EMNE's FDI into developed host countries, it is likely to be influenced by configurations of factors that involve causal asymmetry, namely factors with core and peripheral influences. Accordingly, we propose:

Proposition 2. The process-position-path configurations that drive localized learning are characterized by a core and a periphery.

\subsection{Actor-specific causal configurations}

Causal configurations are actor-specific rather than generally applicable, that is, the configurations that deliver the desired outcome for one type of actor may not work the same for another type of actor. In our context, we propose that the process-positionpath configurations that motivate localized learning differ between the perspectives of headquarters and subsidiaries. Localized learning requires the investing firm to adopt a local responsive mentality in its FDI in order to identify and acquire locally unique strategic assets that can contribute to the knowledge base and competitiveness of the investing firm. Situational contingencies at the subsidiary level are emphasized in local responsive FDI operations (Ghoshal \& Nohria, 1989). In contrast, a global integrative mentality focuses on strategic consistency and coordination at the corporate level, de-emphasizing host country local conditions and contingencies at the subsidiary level. Although the ultimate goal of localized learning is to reverse transfer knowledge back to the corporate level to enhance the global competitiveness of EMNEs, the learning needs to first occur at the subsidiary level (Erramilli, 1991). Thus differences can exist in the type and intensity of knowledge requirements by the headquarters and the subsidiaries, leading to different levels of motivation for localized learning. Birkinshaw (1996) suggests that headquarters should be sensitive to what subsidiary managers think about indigenous contingencies in a specific environment because local managers are in a better position to screen and appraise local dynamics and impediments. Nonetheless, given their corporate level strategic objectives, headquarters often regulate subsidiary practices through internal institutions, which may not be consistent with subsidiary preferences (Kostova \& Roth, 2002). Given this potential divergence between headquarters and subsidiaries with regard to motivation for localized learning, we propose that their respective motivations are likely to be influenced by different configurations of processposition-path conditions.

Proposition 3. The configurational determinants of localized learning demonstrate systematic difference between headquarters and subsidiary levels of EMNEs.

\section{Methods}

\subsection{Sampling design}

This study aims to accurately portray the characteristics and insights of Chinese FDI in Australia, a phenomenon with a relatively short history and a high level of concentration in a limited number of cases. There were approximately 30-40 Chinese MNEs that have substantially operated in about 45-55 FDI projects in Australia by the end of 2008 (CCCA, 2009). Australia has been a priority destination for Chinese outward FDI in recent years (Fan et al., 2012; KPMG, 2013; MOFCOM, 2012), exceeding United States and United Kingdom in terms of Chinese FDI in-flow during 2005-2009 (Economist Intelligence Unit, 2010). We adopt a theoretical sampling principle in terms of case selection. We focus on representative cases with a comprehensive coverage of industries and ownership types. Our case selection includes eleven FDI project cases of Chinese MNEs operating in Australia, for which we interviewed senior executives at both headquarters and Australian subsidiary levels. The four industries that account for the majority of Chinese MNEs operating overseas, namely (a) energy/mining/resources, (b) finance/banking, (c) trading, and (d) manufacturing, are represented in the cases selected. Data collection, from interviews and documentary sources, was designed to generate insights regarding how industry type, ownership form, entry mode strategies, and geographical location impact on Chinese MNE managers' views regarding localized learning. A profile of the selected MNEs is presented in Table 1.

Table 1

An analytic profile of case FDI project operated by Chinese MNEs.

\begin{tabular}{|c|c|c|c|c|c|c|c|c|c|}
\hline $\begin{array}{l}\text { FDI } \\
\text { project }\end{array}$ & $\begin{array}{l}\text { Case } \\
\text { Chinese MNE }\end{array}$ & Ownership & Major product/service & $\begin{array}{l}\text { Going } \\
\text { global }^{\mathrm{a}}\end{array}$ & $\begin{array}{l}\text { Location in } \\
\text { Australia }\end{array}$ & $\begin{array}{l}\text { Entry } \\
\text { mode }\end{array}$ & $\begin{array}{l}\text { Establishment } \\
\text { method }\end{array}$ & Sector & $\begin{array}{l}\text { Interviewee } \\
\text { code }\end{array}$ \\
\hline FDI 1 & MNE1 & State-owned & Oil and gas & 1990s & WA & WOS & Greenfield & Oil and gas & HQ1, AS1 \\
\hline FDI 2 & MNE1 & State-owned & Oil and gas & $1990 \mathrm{~s}$ & Qld & JV & $M \& A$ & Gas & HQ2, AS2 \\
\hline FDI 3 & MNE2 & State-owned & $\begin{array}{l}\text { Alumina and primary } \\
\text { aluminium production }\end{array}$ & $2000 s$ & Qld & WOS & Greenfield & $\begin{array}{l}\text { Industrial metals } \\
\text { and mining }\end{array}$ & HQ3, AS3 ${ }^{\mathrm{b}}$ \\
\hline FDI 4 & MNE2 & State-owned & $\begin{array}{l}\text { Alumina and primary } \\
\text { aluminium production }\end{array}$ & $2000 s$ & Vic & JV & Greenfield & $\begin{array}{l}\text { Research and } \\
\text { development }\end{array}$ & HQ4, AS4 \\
\hline FDI 5 & MNE3 & State-owned & Chemical materials & $1990 s$ & Vic, NSW & WOS & $\mathrm{M} \& \mathrm{~A}$ & Manufacturing & HQ5, AS5 ${ }^{\mathrm{b}}$ \\
\hline FDI 6 & MNE4 & State-owned & $\begin{array}{l}\text { Commercial banking, } \\
\text { investment and insurance }\end{array}$ & 1920 s & NSW, Vic, WA & WOS & Greenfield & $\begin{array}{l}\text { Banking and } \\
\text { financial service }\end{array}$ & HQ6, AS6 \\
\hline FDI 7 & MNE5 & State-owned & $\begin{array}{l}\text { Gold, copper and } \\
\text { other metals }\end{array}$ & $2000 s$ & SA, Qld & JV & $M \& A$ & $\begin{array}{l}\text { General metals } \\
\text { and mining }\end{array}$ & HQ7, AS7 \\
\hline FDI 8 & MNE6 & State-owned & $\begin{array}{l}\text { Power generation } \\
\text { and energy service }\end{array}$ & $2000 s$ & Qld & JV & $M \& A$ & Power and energy & HQ8, AS8 ${ }^{\mathrm{b}}$ \\
\hline FDI 9 & MNE7 & State-owned & $\begin{array}{l}\text { Electricity generation } \\
\text { and service }\end{array}$ & $2000 s$ & NSW, WA & JV & $M \& A$ & Electricity & HQ9, AS9 \\
\hline FDI 10 & MNE8 & Private & Coke related products & $1990 s$ & Qld, NSW & WOS & Greenfield & $\begin{array}{l}\text { Mining and industrial } \\
\text { manufacturing }\end{array}$ & HQ10, AS10 \\
\hline FDI 11 & MNE9 & State-owned & $\begin{array}{l}\text { Machinery and } \\
\text { equipment import } \\
\text { and export }\end{array}$ & $1970 s$ & Vic, NSW & WOS & Greenfield & Trading & HQ11, AS11 \\
\hline
\end{tabular}

a (1): Date/period when the film internationalized its operations. No specific year is given due to research ethics to protect anonymity. WOS: wholly owned subsidiary,

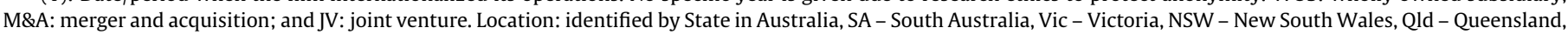

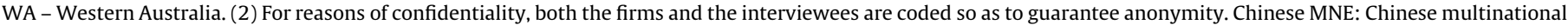
enterprises. HQ: headquarters of the MNE. AS: Australian subsidiary.

b The interviews were conducted in English as the interviewees are native English speakers and are from an Australian cultural background. 
Table 1 also details ownership characteristics. The selected firms mirror the norm for Chinese MNEs in that the overwhelming majority are state owned enterprises (SOEs) (Rugman \& Li, 2007; Zhang \& Van Den Bulcke, 1996). Case selection, however, did not ignore the existence of private Chinese multinationals and hence one privately owned firm was included. Selection was also informed by an awareness that although Chinese MNEs commonly undertake joint ventures, they generally prefer to establish wholly owned subsidiaries (WOS) as the entry mode (Cui \& Jiang, 2009). In 2008 the first named author spent nearly five months on fieldwork. This was conducted in several cities in China (e.g., Beijing, Tianjin, Shanghai, and Taiyuan) and in Australia (e.g., Brisbane and Melbourne) where the case FDI's headquarters and subsidiaries are located. During the data collection period, twenty-two semi-structured interviews were conducted at both headquarters and Australian subsidiary levels among eleven FDI projects of nine Chinese multinationals (see coding in Table 1).

All of the twenty-two interviewees were identified as executives who played important roles in strategic decision-making. Eleven participants were senior executives at headquarters level who held positions ranging from chief executive officer (CEO), executive member of the board of directors, vice-general manager, to chief operations officer ( $\mathrm{COO}$ ) and international project director. of the eleven executives interviewed at the subsidiary level, nine held either the CEO or general manager position. The other two interviewees were project directors. All participants were interviewed either face-to-face, or through pre-arranged telephone interviews. Each interview was approximately one and a half hours. Where the participants agreed, interviews were recorded by digital recorder. Notes were taken when interviews could not be recorded. Also notes, including all the details discussed and specific views expressed by the interviewees and impressions of the researcher were written up without delay. As the majority of interviews (nineteen out of twenty-two interviews as noted in Table 1) were conducted in Mandarin, transcripts were recorded in this language and sent to the interviewees for comment. Their feedback was incorporated into the transcripts. The latter were then translated into English and analysis was undertaken utilizing the English transcripts.

\subsection{Analytical approach}

We explore our research question following a configurational set-theoretic approach utilizing the technique of fuzzy-set qualitative comparative analysis (fsQCA). Grounded in set theory, fsQCA is an analytic technique that allows for a detailed analysis of how causal conditions contribute to an outcome in question (Crilly, 2011; Fiss, 2007, 2011; Ragin, 2008). The fsQCA technique is particularly suited for analysing causal processes in this study when compared to conventional statistical methods (e.g., Pajunen, 2008; Schneider, Schulze-Bentrop, \& Paunescu, 2010). First, fsQCA models the concept of conjunctural causation, that is, the idea that combinations of various causal conditions, rather than one condition alone, are linked to the outcome (Schneider et al., 2010). While traditional regression based analysis can examine interaction effects, it is usually limited to three-way interactions due to statistical power considerations. Second, multiple causal paths can be detected by fsQCA, which provide more than one possible combination of causal conditions that can be linked to the same outcome. In other words, the fsQCA approach captures potential equifinality, a situation where "a system can reach the same final state from different initial conditions and by a variety of different paths" (Fiss, 2007: 1181). This allows for discovering whether different configurations of internal and external conditions can contribute to the motives of localized learning. Third, fsQCA is well suited for a small sample size (Ragin, 2008), which is likely to be the case for studying an emerging phenomena with limited information in scope and depth.

This study employs a set-theoretic approach based on fsQCA. While fsQCA can operate with any number of cases (Ragin, 2008), Fiss (2007: 1194) suggests that fsQCA is ideal for "allowing the analysis of small-N situations, that is, situations where the number of cases is too large for traditional qualitative analysis and too small for many conventional statistical analysis (e.g., between ten and fifty cases)." A number of studies (e.g., Basurto, 2013; Ragin, 2008) have reasonably applied fsQCA in the scale of less than fifteen (or even less than ten) case studies. As such, fsQCA is deemed suitable for the analysis of the eleven FDI cases in our sample.

\subsection{Calibration}

Compared with most studies that apply fsQCA to analyze secondary data at the firm level, there have been fewer studies focusing on in-depth perceptual data from primary sources. The major reason for the lack of qualitative comparative analysis for qualitative data is the under-development of a calibration standard ("best practice") (Basurto \& Speer, 2012). Metelits (2009) criticizes studies that use qualitative data for an fsQCA because they lack transformation details of calibration.

Addressing this methodological limitation, this study adopts the multi-step structured calibration approach for qualitative data illustrated by Basurto and Speer (2012) and several "best practice" examples (i.e., Crilly, 2011; Fiss, 2011; Ragin, 2008). First, all six causal conditions and the outcome were identified by the dynamic capability framework. Following the recommendation made by Berg-Schlosser and De Meur (2009: 14) - "a common practice in an intermediate- $\mathrm{N}$ analysis (say, 10 to 40 cases) would be to select from 4 to 6-7 conditions."

Second, a list of anchor points of each fuzzy set was prepared before developing the interview protocol. Anchor points, such as, 1 (full membership), 0.5 (cross-over point) and 0 (absence of membership) can help researchers clarify how to distinguish a case that is more in the set, from a case that is less in the set (Ragin, 2008). For example, a number of countries have explicitly encouraged business modularization (that is, standardized components, and sourced from local suppliers) when attracting and approving FDI projects, and even have required 40 percent to 90 percent domestic content for investing in some selected industries (e.g., oil and gas exploration, wind turbines, automobiles, and telecommunications equipment in Brazil and China) (Ezell, Atkinson, \& Wein, 2013; Haley \& Haley, 2013). By considering several references, such as, the government agency (i.e., Foreign Investment Review Board), the industry association (i.e., Australian Mines and Metals Association), and other sources (i.e., key publications from World Trade Organization and Academy of International Business), we generally set a $30 \%$ business modularization rate as a cross-over point, $70 \%$ above as full membership, while $5 \%$ less as non-membership.

Third, Ragin (2008) suggests that the number of causal conditions can be kept low by using higher order concepts that incorporate several variables. Hence we asked interview questions related to these general concepts, such as established network resources and so on. These in-depth interviews were triangulated by observation and relevant archival files of each FDI project. Once raw interview data was collected, we developed an initial list of codes based on our key concepts and the preliminary list of measure of the conditions and the outcome that we mentioned above. A content analysis was applied and all quotations within one case for each case, was summarized. We then reviewed our qualitative data in three ways suggested by Basurto and Speer (2012), namely, to review each code across all interviewees, to review each code by classifying interviewees in each case FDI project, and to review each code across all FDI projects at both 
headquarters (HQ) and Australian subsidiary (AS) levels. In so doing, triangulation is warranted, and systematic biases in responses are maintained to a minimum level.

Fourth, based on the definition of the fuzzy-set values on the theoretical concept of interest and on our in-depth knowledge of the cases and the particular FDI project context, all six casual conditions are calibrated into the four-value fuzzy set, which inserts "more in than out" marked 0.67 and "more out than in" marked 0.33 for causal conditions in addition to full membership in a set of interest (marked as 1) while full non-membership marked as 0 . Finally, we reviewed the calibration results and attempted to revise and adjust the assigned fuzzy-set values, which is "a crucial part of the dialogue between theory and evidence" (Basurto \& Speer, 2012: 167), because it allows us to evaluate whether the fuzzy-set value differences between cases reflect real differences between the cases according to case knowledge and whether interview data are well captured by the calibration. A sample of such a detailed transformation is demonstrated in Table 2.

The calibration of the outcome - the motivation for localized learning was undertaken by a two-step procedure. At the first step, when the first named researcher approached these interviewees and explained the purpose of this study, a previous drawn integration - responsiveness framework was provided to decision makers, and asked them to best position their current and preferred international business strategies within the four-fold Bartlett-Ghoshal typology (see, Bartlett \& Ghoshal, 1998). Once the participants identified their strategic positions, relevant archival files (such as, annual reports, corporate documents and meeting minutes) were referred to assess the accuracy of their strategic positions marked and the likelihood of variance between their strategic mind-sets and the factual state.

At the second step, we asked these interviewees again in regard of their perception on the degree of localized learning after having examined all factors possibly affecting the degree. Each interviewee explained the rationale of their strategic choice and why such a choice on the degree of localized learning reflects their concurrent operation overseas. In the majority of situations, these interviewees confirmed their strategic preference on the degree of localized learning. To calibrate this variable, the motivation for localized learning was transformed to the six-value fuzzy set. The calibration sets up a rank order to distinguish each Chinese MNEs' preference on localized learning. Illustrative quotations from the interviews are provided in Table 3.

\section{Results}

We start out by testing whether any of the causal conditions can be considered a necessary condition for the outcome. A condition is called "necessary" or "almost always necessary" if the condition is required but not necessarily sufficient for an outcome to occur (Ragin, 2008; Schneider et al., 2010). As shown in Table 4, we analyzed whether any of the six causal conditions are necessary to account for localized learning. None of the individual conditions exceeded the consistency threshold of 0.90 (Schneider et al., 2010). The consistency measure for market competition in the HQ data set assumes a value of 0.85 , the highest value among all conditions.

The truth table algorithm is presented in Table 5, which functions combinatorial logic design behaviour (Ragin, 2008). The truth table algorithm adopts counterfactual analysis to speculate about the most theoretically plausible outcomes of the combinations that do not exist in the data set (Crilly, 2011; Fiss, 2011; Ragin, 2008). As shown in Table 5, causal combinations of conditions exceeding an appropriate cut-off consistency score are categorized as sufficient, and the outcome is therefore assigned a value of 1 in the table. Conversely, causal combinations with a consistency level below or at the cut-off value are not considered sufficient, and the outcome is assigned a value of 0 . Setting a frequency threshold of one observation is usually advised for a relatively small sample (cf. Crilly, 2011; Ragin, 2008), and also this is an operational strategy (cf., Crilly, 2011; Hotho, 2014; Judge, Fainshmidt, \& Brown, 2014) for dealing with the limited diversity of combinations (that is, the logically possible causal combination $-2^{k}$ possibilities, such as $2^{6}$ in this study, exceeds the sample size). One guideline is to select a threshold that corresponds to a break observed in the distribution of consistency scores (e.g., Crilly, Zollo, \& Hansen, 2012; Schneider et al., 2010). Following this approach, we applied a cut-off value of 0.869 at the HQ dataset while 0.880 at the dataset of Australian subsidiary, combinations of causal conditions and outcome reported.

Table 6 shows the results of our fuzzy set analysis of localized learning at both headquarters and Australian subsidiary levels. The notation for solution are presented based on the most influential fsQCA presentation style introduced by Ragin \& Fiss, 2008Ragin and Fiss (2008; see more in Crilly, 2011; Fiss, 2011; Hotho, 2014; Ragin, 2008). Under the notation, black circles $(\bullet)$ indicate the presence of a condition, and circles with " $X$ " $(\otimes)$ indicate its absence. Large circles indicate core conditions while small ones are peripheral conditions. Blank spaces indicate 'don't care' situations in which the causal condition may be either present or absent. Solutions are grouped by their core conditions. The solution tables only list configurations that consistently led to the outcome of interest; and the tables do not include configurations that do not lead to localized learning, that did not pass the frequency threshold, or that showed no consistent pattern and thus did not pass the consistency threshold.

Based on the Quine-McCluskey algorithm (the method of prime implicants) that gives a deterministic way to check that the minimal form of a Boolean function has been reached, the solution table shows the fuzzy set analysis results in four major solutions and furthermore indicates the presence of both core and peripheral conditions as well as neutral permutations of two configurations for both the headquarters and Australian subsidiary levels. The presence of several overall solutions thus points to a situation of first-order, or across-type, equifinality of solutions (e.g., Fiss, 2011). The neutral permutations within solutions 1 (1a and 1b) further illustrates the existence of second-order, or within-type, equifinality.

Two measures of fits, namely consistency and coverage, are reported in Table 4. The consistency score measures how well the solution corresponds to the data (Crilly, 2011; Ragin, 2008). The score is calculated for each configuration separately, and for the solutions as a whole. The measure of consistency can range from 0 to 1 (Ragin, 2008), with a high value indicating greater consistency between the theoretical relationship and the actual data. Previous studies (e.g., Fiss, 2011; Hotho, 2014) suggest an acceptable consistency $(\geq 0.80)$. Schneider et al. (2010) choose a threshold that corresponds to a gap observed in the distribution of consistency scores. Following that approach, we apply a threshold of 0.869 at the HQ dataset while 0.880 at the dataset of Australian subsidiary. In the study, we reported all solutions here -0.92 for the whole solution at the HQ level while 0.93 for the whole solution at the Australian subsidiary level, and between 0.87 and 0.90 for each individual solutions for both the HQ and Australian subsidiary levels. The consistency scores demonstrate the presence of clear set-theoretic relationship. In other words, we find support to our Proposition 1 that configuration of process-position-path factors affect EMNE's motivation to engage in localized learning in developed host countries.

The second fit indicator measures solution coverage. We obtain a coverage of 0.57 for the headquarters level, and a coverage of 
Table 2

A sample of calibration of causal conditions.

\begin{tabular}{|c|c|c|c|c|}
\hline \multirow[t]{2}{*}{ Causal conditions } & 0 (absence of membership) & 0.33 (partial membership) & 0.67 (partial membership) & 1 (full membership) \\
\hline & \multicolumn{4}{|l|}{ Illustrative quotations } \\
\hline Market orientation & $\begin{array}{l}\text { "We will ship about all coke } \\
\text { related products back to China } \\
\text { as the mining project was } \\
\text { initially designed for. So this is } \\
\text { our market orientation. We } \\
\text { don't consider market } \\
\text { orientation as a driven force for } \\
\text { localised learning" HQ10, } \\
\text { FDI10. }\end{array}$ & $\begin{array}{l}\text { "We sell electricity to the local } \\
\text { market, so our market } \\
\text { orientation is here. However, } \\
\text { the market orientation itself } \\
\text { does not really attract our } \\
\text { attention in terms of [localized] } \\
\text { learning. It might have an } \\
\text { indirect impact... I guess... } \\
\text { Anyway, I don't think this } \\
\text { factor is important to localize }\end{array}$ & $\begin{array}{l}\text { "We control 70\% local [Australian] } \\
\text { market. To maintain our market } \\
\text { leader status, localized learning } \\
\text { would be more likely helpful" HQ5, } \\
\text { FDI5. }\end{array}$ & $\begin{array}{l}\text { "HSBC [Hong Kong and Shanghai } \\
\text { Banking Corporation] has set an } \\
\text { excellent landmark for us, such as } \\
\text { their slogan, 'The World's Local Bank', } \\
\text { which does not only show their } \\
\text { strategic goals, but also market } \\
\text { orientation. Being a local bank, we } \\
\text { certainly need to pay attention on } \\
\text { localized learning” HQ6, FDI6. }\end{array}$ \\
\hline
\end{tabular}

Business modularization "This factor is not relevant to our industry [machinery $\mathcal{E}$ equipment importing $\mathcal{E}$ exporting]" HQ11, FDI11.

Network resources

"We don't place value on this factor as our management philosophy is simply market driven" HQ11, FDI11.

factor is important to localize our learning in Australia" AS9, FDI9.

"We have to outsource some engineering contracts to locals as we need to comply with local standards. Dealing with local companies is somewhat facilitating our localized learning" AS2, FDI2.

"Network resources have certain impact on localized learning, but building good network in Australia is very difficult for us" AS10, FDI10.

Business specificity "I don't think our business or our Australian subsidiary's business is special" AS11, FDI11.

"The industry [resource] makes us look special. We need people who have specialized knowledge and experience work in this field. However, the industry is operated in a highly standardized and globalized world. Business specificity is not my major concern for learning local" HQ2, FDI2.

Institutional complexity “We are 'oil people' who are doing oil businesses around the globe. We fly to other countries and back here [Beijing, China] almost every week Institutional complexity is not our concern" HQ1, FDI1.

Market competition

"We are competing in a global industry. I don't think Australian domestic competition is a matter for us" HQ1, FDI1.
"I don't think institutional issues are complex here

[Australia], maybe because I am a local. However I can feel some business culture difference between our HQ and here. So it might be an issue for our colleagues who are expats from HQ" AS5, FDI5

\section{"Australia is reputable for its} strong mining and resource sector, but we are also a world leader in the industry, we have own unique advantages to avoid severe competition here [in this particular industry]" AS3, FDI3.
"You know, we took the mining project completely from a French company. We still need to rely on existing local contractors for keeping developing the mining infrastructure" AS3, FDI3.

"Local network is important for driving localized learning, but it does not necessarily mean good local network resources would solely produce positive localized learning outcomes" HQ4, FDI4.

"because of the specificity of our business, we certainly need to consider some environmental issues, such as Australian natural environment evaluation standards, which are also very different from ours at home, ... the impact of our business specificity on localized learning is high" HQ7, FDI7.

"I have been to Australia several times. My observation is the two institutional contexts are quite different. So we need to learn the local [institutional] context, but we invested several countries, institutional complexity is not a serious block" HQ10, FDI10.

"Local market is quite competitive for our company. We actively respond such competition from both local and global, so we invest in this research and development orientated project and closely work with local research institutions in order to enhance our competitiveness" AS4, FDI4. “...business modularization can build better relationships with local suppliers, which is very important for localized learning" AS1, FDI1.
"I think the factor, such as establishing local network, and obtaining government support, has significant impact on localized learning, especially for running mining businesses, the influence would be obvious" HQ7, FDI7.

"Absolutely, we are operating in a special industry with both risk to environment and high technology components. Continually learning local colleagues to innovate, improve the operation procedure, and their good experience on controlling process parameters would be very important for our operation worldwide and localization as well." HQ5, FDI5.

"Institutional difference is obvious. That is why we need to make more efforts on localized learning" HQ3, FDI3.

"Australian electricity market is highly competitive as a number of global players are in this industry. I have been serving for several companies in the field, so my suggestion is Chinese companies must localize their learning and act like local.. That is the only way they can stay in market" AS8, FDI8.

0.46 for the Australian subsidiary level, which indicates the empirical importance of the solution as a whole (Crilly, 2011; Ragin, 2008). The raw coverage measures the explanatory power of an individual configuration. However, any single observation might be explained by multiple configurations, therefore, a measure of each configuration's unique contribution to the explanation of affecting localized learning is provided.

Since the fsQCA was undertaken at both the headquarters and the subsidiary levels, two Boolean equations (cf. Crilly, 2011) linked to localized learning are reported respectively as below:

$$
\begin{aligned}
\text { LOCALIZEDLEARNING }_{\mathrm{HQ}}= & \mathrm{MO} * \sim \mathrm{BM} * \sim \mathrm{NR} * \sim \mathbf{B S} * \mathrm{IC} * \mathbf{M C} \\
& +\mathrm{MO} * \sim B M * \mathrm{NR} * \sim \mathbf{B S} \sim \mathrm{IC} * \mathbf{M C} \\
& +\mathbf{M O} * \sim B M * \mathbf{N R} * B S * \mathbf{I C} * \sim \mathrm{MC}
\end{aligned}
$$

LOCALIZEDLEARNING $_{\mathrm{AS}}=\sim \mathrm{BM} * \mathrm{NR} * \mathrm{BS} * \sim \mathbf{I C} * \sim \mathrm{MC}$

$$
+\mathbf{M O} * \sim \mathbf{B M} * \sim \mathbf{N R} * \sim \mathbf{B S} * I C * M C
$$

The two Boolean equations report intermediate solutions calculated from fsQCA, which is preferred and standard for reporting purpose suggested by Ragin (2008) and among others 
Table 3

A sample of calibration of outcome - localized learning.

\begin{tabular}{|c|c|c|}
\hline Outcome & Calibration & Rationale and quotes \\
\hline \multirow[t]{6}{*}{ Localized learning } & 0 (fully out) & $\begin{array}{l}\text { Chinese multinationals do not see the necessity of localizing their learning via FDI projects in Australia. } \\
\text { Example: "We are in a highly global integrated industry. Localized learning would be time consuming, } \\
\text { unnecessary, and distract our focus. Once again, we lay stress on people, money and reserves" (HQ1, FDI1, Lines: } \\
\text { 160-161, 170-172; Beijing, China). }\end{array}$ \\
\hline & 0.2 (mostly but not fully out) & $\begin{array}{l}\text { Chinese multinationals recognize the role of localized learning though it plays rather limited role in their } \\
\text { FDI projects in Australia: Example: "Look, we understand the concept of localized learning, but as you know, we } \\
\text { do not emphasize it as our product [of FDI 10] is sold back to our market in mainland [of China]" (AS10, FDI10, } \\
\text { Lines: 281-282; Melbourne, Australia). }\end{array}$ \\
\hline & 0.4 (more or less out) & $\begin{array}{l}\text { Chinese multinationals prefer to involve in localized learning, but the degree of localized learning is limited } \\
\text { by their internationalization capabilities. Example: "We consider to be a localized firm but localized learning } \\
\text { requires socialization, commitment and adaptation in the host country, which I have to admit that we don't have } \\
\text { capabilities to handle as a relatively new entrant to the market [Australia] though we have made some } \\
\text { attempts"(AS7, FDI7; Lines 165-170; Perth, Australia). }\end{array}$ \\
\hline & 0.6 (more or less in) & $\begin{array}{l}\text { Chinese multinationals pay attention on the important role of localized learning in their Australian FDI } \\
\text { project, but they also reconcile the strong needs of global learning. Example: "Australian subsidiaries have } \\
\text { become profitable and competitive in the Australian power generation market and we understand the importance } \\
\text { of localized learning. We commit to the Australian national interest, learn from the local management team, and } \\
\text { serve local communities. But for achieving our goal [to become one of Wold Top } 500 \text { Companies], we tighten up } \\
\text { our global integration in order to achieve economies of scale. For instance, our businesses in Australia (i.e., M plant } \\
\text { and C plant) not only contribute to the total generation capacity, but also about 50\% coal produced from our } \\
\text { Australian coal mines will be sold back to our domestic (in Mainland China) plants" (HQ8, FDI8; Lines: 67-69, } \\
90,110-115 \text {; Beijing, China). }\end{array}$ \\
\hline & 0.8 (mostly but not fully in) & $\begin{array}{l}\text { Chinese multinationals are experiencing significant localized learning in their FDI projects in Australia, and } \\
\text { treat it as a way of enhancing dynamic capability. Example: "The tendency of our business strategy is to } \\
\text { increase the decentralized management. We are experiencing the transition from the highly centralized } \\
\text { management to decentralized management. Integration is not currently our main consideration, rather we now } \\
\text { mention localization, or in your terms, pay more attention on localized learning; that is, we need to consider how } \\
\text { to improve our subsidiaries' operation and ability to compete in local markets, and how we can take into account } \\
\text { local characteristics" (HQ6, FDI6; Lines: } 146-150 \text {; Beijing, China). }\end{array}$ \\
\hline & 1 (fully in) & $\begin{array}{l}\text { Chinese multinationals fully rely on localized learning to improve their competitive advantages when } \\
\text { operating in Australia. Example: "I think that the strategy of MNE3 is multi-domestic. Our Beijing office (the HQ) } \\
\text { implemented what they committed to us ['do-nothing policy'] before the merging case - to remain an Australian } \\
\text { company managed by Australians. Actually it is a smart way to manage this company [Australian subsidiary], } \\
\text { because we know better about our local trade persons and the market as well" (AS5, FDI5; Lines: 127-129, 130- } \\
\text { 132; Melbourne, Australia). }\end{array}$ \\
\hline
\end{tabular}

(e.g., Hotho, 2014; Schneider et al., 2010). The intermediate solution is "a subset of the most parsimonious solution and a superset of the most complex solution (Ragin, 2008: 203). Each line represents a configuration of conditions associated with the degree of localized learning. In addition, we also highlighted causal conditions that appear in parsimonious solution as Ragin and Fiss (2008: 204) argue that "the terms included in the parsimonious solution must be included in any representation of the results, for these are the decisive causal ingredients that distinguish combinations of conditions that are consistent subsets of the outcome from those are not. Thus, these ingredients should be considered the 'core' causal conditions". The star $\left({ }^{*}\right)$ represents the Boolean logic term AND while the plus sign $(+)$ represents the Boolean term OR. The tilde $(\sim)$ means the Boolean logic term NOT (cf. Crilly, 2011).

Table 4

Analysis of necessary conditions.

\begin{tabular}{|c|c|c|c|c|}
\hline \multirow[t]{2}{*}{ Conditions } & \multicolumn{2}{|c|}{ At the HQ level } & \multicolumn{2}{|c|}{$\begin{array}{l}\text { At the Australian } \\
\text { subsidiary level }\end{array}$} \\
\hline & Consistency & Coverage & Consistency & Coverage \\
\hline Market orientation (MO) & 0.74 & 0.75 & 0.63 & 0.79 \\
\hline $\begin{array}{l}\text { Business modularization } \\
\text { (BM) }\end{array}$ & 0.30 & 0.60 & 0.34 & 0.56 \\
\hline Network resources (NR) & 0.74 & 0.69 & 0.78 & 0.57 \\
\hline Business specificity (BS) & 0.55 & 0.69 & 0.77 & 0.54 \\
\hline $\begin{array}{l}\text { Institutional complexity } \\
\text { (IC) }\end{array}$ & 0.76 & 0.56 & 0.80 & 0.52 \\
\hline $\begin{array}{l}\text { Market competitiveness } \\
\text { (MC) }\end{array}$ & 0.85 & 0.63 & 0.84 & 0.57 \\
\hline
\end{tabular}

Note: Calculation with the fsQCA 2.5 software.

\subsection{Configurational Solutions at the Headquarters Level}

The first two configurations include two neutral permutations 1a (MO $^{*} \sim \mathrm{BM}^{*} \sim \mathrm{NR}^{*} \sim$ BS$^{*} \mathrm{IC}^{*}$ MC) with an empirical case FDI 11 , and $1 \mathrm{~b}\left(\mathrm{MO}^{*} \sim \mathrm{BM}^{*} \mathrm{NR}^{*} \sim \mathbf{B S} \sim \mathrm{IC}^{*} \mathbf{M C}\right)$ that refers to FDI 6 at the headquarters level. The two configurations reflect the key motivating effect of host country market competition on EMNE's localized learning in developed host countries, and the demotivating role of business specificity. That is, the headquarters decision makers of FDI11 and FDI6 do pay attention to the competition intensity affecting their decision on the extent to which they should act as locally responsive learners, but they will be unwilling to operate or learn in a localized manner if their FDI is characterized with highly specific practices and routines. This is echoed with a quote from a senior executive of FDI6:

"Our bank must follow some international regulations when internationalizing our businesses, such as Basel Concordat. Of course we also need to consider local regulations as well, ... but in Australia, our localized learning and operations would be limited by our business specificity. For example, we cannot think of expanding our business to the insurance industry. We can't because we are limited by our business license." [HQ6, FDI6]

This finding implies that for an EMNE to engage in localized learning, it needs to standardize its operational practices to be locally compatible. As shown in Table 6, in solutions $1 \mathrm{a}$ and $1 \mathrm{~b}$, market orientation is a contributing factor affecting localized learning, whereas business modularization is a negative factor. While solutions $1 \mathrm{a}$ and $1 \mathrm{~b}$ are identical configurations in terms of core conditions, they differ at the peripheral level. Specifically, 
Table 5

Truth table based on the fuzzy-set data matrix (logical remainders not listed).

\begin{tabular}{|c|c|c|c|c|c|c|c|c|}
\hline \multicolumn{6}{|c|}{ Causal conditions } & \multicolumn{2}{|l|}{ Outcome } & \multirow{2}{*}{$\begin{array}{l}\text { Cases with set } \\
\text { membership }>.5\end{array}$} \\
\hline MO & $\mathrm{BM}$ & NR & BS & IC & MC & Localized learning & Consistency & \\
\hline \multicolumn{9}{|c|}{ At the HQ level } \\
\hline 1 & 0 & 1 & 0 & 0 & 1 & 1 & 0.90 & FDI6* \\
\hline 1 & 0 & 1 & 1 & 1 & 0 & 1 & 0.87 & FDI5* \\
\hline 1 & 0 & 0 & 0 & 1 & 1 & 1 & 0.87 & FDI11* \\
\hline 0 & 0 & 1 & 1 & 0 & 1 & 0 & 0.80 & FDI8 \\
\hline 0 & 0 & 1 & 1 & 1 & 1 & 0 & 0.63 & FDI7 \\
\hline 0 & 1 & 1 & 1 & 1 & 1 & 0 & 0.60 & FDI9 \\
\hline 0 & 1 & 1 & 0 & 1 & 0 & 0 & 0.60 & FDI4 \\
\hline 1 & 0 & 0 & 0 & 0 & 0 & 0 & 0.30 & FDI1 \\
\hline \multicolumn{9}{|c|}{ At the Australian subsidiary level } \\
\hline 1 & 0 & 0 & 0 & 1 & 1 & 1 & 0.90 & FDI11* \\
\hline 1 & 0 & 1 & 1 & 0 & 1 & 1 & 0.90 & FDI5* \\
\hline 0 & 0 & 1 & 1 & 0 & 1 & 0 & 0.88 & FDI8 \\
\hline 0 & 0 & 1 & 1 & 1 & 1 & 0 & 0.78 & FDI7 \\
\hline 1 & 0 & 1 & 1 & 1 & 1 & 0 & 0.77 & FDI6 \\
\hline 0 & 1 & 1 & 1 & 1 & 0 & 0 & 0.77 & FDI3 \\
\hline 0 & 1 & 0 & 1 & 1 & 1 & 0 & 0.73 & FDI4 \\
\hline 0 & 0 & 1 & 0 & 1 & 1 & 0 & 0.72 & FDI2 \\
\hline 0 & 1 & 1 & 0 & 1 & 1 & 0 & 0.55 & FDI1 \\
\hline
\end{tabular}

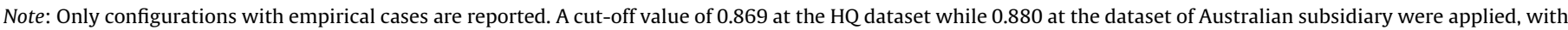
consistency scores rounded to two decimal places. Case FDI with '*' sign is emphasized in this study.

they represent alternative configurations where network resources and institutional complexity replace the role of each other.

When headquarter decision makers perceive less confidently about their network resources in the host country, the awareness of host country institutional complexity has become an embedded part of their localized learning for building dynamic capability. Therefore, their localized learning efforts do not need to be motivated by their strategic positions, such as whether or not they have network resources and specialized business practices (that is, the case of FDI11). For example, a senior executive of FDI11 at its headquarters clearly states:

We were one of pioneers among all Chinese firms investing in Australia. We established two wholly-owned subsidiaries in

Table 6

Configurations for localized learning.

\begin{tabular}{|c|c|c|c|c|c|}
\hline \multirow[t]{2}{*}{ Configuration } & \multicolumn{3}{|c|}{$\begin{array}{l}\text { Solution at the } \\
\text { headquarters (HQ) level }\end{array}$} & \multicolumn{2}{|c|}{$\begin{array}{l}\text { Solution } \\
\text { at the } \\
\text { Australian } \\
\text { subsidiary } \\
\text { (AS) level }\end{array}$} \\
\hline & $1 \mathrm{a}$ & $1 \mathrm{~b}$ & 2 & 3 & 4 \\
\hline \multicolumn{6}{|l|}{ Process } \\
\hline Market orientation & $\bullet$ & $\bullet$ & $\bullet$ & & 0 \\
\hline Business modularization & $\otimes$ & $\otimes$ & $\otimes$ & $\otimes$ & $\otimes$ \\
\hline \multicolumn{6}{|l|}{ Positions } \\
\hline Network resources & $\otimes$ & $\bullet$ & ○ & $\bullet$ & $\otimes$ \\
\hline Business specificity & $\otimes$ & $\otimes$ & $\bullet$ & $\bullet$ & $\otimes$ \\
\hline \multicolumn{6}{|l|}{ Paths } \\
\hline Institutional complexity & $\bullet$ & $\otimes$ & $\bullet$ & $\otimes$ & - \\
\hline Market competitiveness & 0 & 0 & $\otimes$ & $\bullet$ & $\bullet$ \\
\hline Consistency & 0.87 & 0.90 & 0.87 & 0.90 & 0.90 \\
\hline Raw coverage & 0.32 & 0.22 & 0.16 & 0.33 & 0.22 \\
\hline Unique coverage & 0.22 & 0.12 & 0.12 & 0.24 & 0.12 \\
\hline Case FDI & FD11 & FD16 & FD15 & FD15 & FD11 \\
\hline Overall solution consistency & & 0.92 & & & \\
\hline Overall solution coverage & & 0.57 & & & \\
\hline
\end{tabular}

Black circles indicate the presence of a condition, and circles with " $\mathrm{X}$ " indicate its absence. Large circles indicate core conditions; small ones, peripheral conditions. Blank spaces indicate "don't care".
Australia in 1985. One is in Melbourne, and the other is located in Sydney. Since our business establishment, we have kept a good relation with governmental officers at different level of governments, local Chinese associations/communities, and local business partners. All these networking efforts did not help our localised learning. ... We are a market driven company, ... we are influenced by local competition and the complexity of Australia shifting their manufacturing operations overseas. [HQ11, FDI11]

However, many of our interviewees have relatively rich international investment experience, higher education backgrounds from the Western countries and long term overseas work experience, and as such they may not perceive significant institutional complexity with countries they intend to make investments in. In line with the findings of Luo (2003), we find that managerial network resources is still a driving force of localizing their learning in host countries because executives tend to increase capabilities with executives at supplier, buyer, competitor, and distributor firms, as well as with government officials. Tan and Meyer (2010: 154) argue "when they [EMNEs] wish to transcend their home context, they need internationally valuable resources, especially managerial resources, which may be quite different than the resources that enable domestic growth", which reflects the importance of localized learning. Hence, if a decision maker does not perceive significant institutional complexity, the 1b solution (FDI6) is more relevant because it emphasizes the driving force of network resources. In other words, the decision maker of FDI6 still needs to pay attention to uncertainty and risks embodied within the complex environment that might be beyond the control of the firm. For example, the senior executive of FDI6 argues:

"I used to be the CEO of the Australian subsidiary. I can feel significant different difference between the two institutional contexts [Australian vs. China]... but we cannot overstate the role of institutional complexity [on localized learning]. After all, we are running an MNE." [HQ6, FDI6]

The third configuration $\left(\mathbf{M O}^{*} \sim \mathrm{BM}^{*}\right.$ NR $\left.^{*} \mathrm{BS}^{*} \mathbf{I C}^{*} \sim \mathrm{MC}\right)$ at the headquarters level highlights three core conditions, namely, market orientation, network resources, and institutional complexity (see Solution 2 in Table 6). The empirical case for this 
solution is FDI5, which refers to a successful merging case made by a Chinese chemical material manufacturing giant -MNE3. This configuration provides decision makers with an alternative solution in configuring their localized learning mind-sets, especially when neither their FDI projects face strong local competition, nor a reliance on local business modularization, and requires them to learn local specific business practices. In this case, the decision makers should place an emphasis on local market (process), utilize managerial network resources (position) and be highly aware of local institutional complexity (path) in order to engage in localized learning. For example, the director of MNE3 describes:

We have a broad range of manufacturing technologies so that we can meet our different customers' needs. From the booklet [the interviewee showed a thick guide of products and applications], you can see how many types of products are in our capabilities. Different products have different safety requirements. You [here mainly means customers] can search all these data from our pretty comprehensive database, and we serve a range of industry users. All these require us to concentrate on our market [the host country - Australia].

We rely on our local managers as they know better than us in terms of local networks. We provide autonomy to the CEOs or COOs [in subsidiaries] as high as we possibly can.

The host country's legal system represents a minefield for Chinese MNEs to negotiate; the effective way to overcome such barriers is to have local best agency or the world top class consulting firms in our FDI projects. [HQ5, FDI5]

In contrast to the first two configurations at the headquarters level, the findings clearly indicate that the process-position-path configurations of localized learning determinants are characterized simultaneously by a core and a periphery. Therefore, Proposition 2 is supported.

\subsection{Configurational solutions at the subsidiary level}

Table 6 demonstrates that decision makers at the Australian subsidiary level have considerably different views compared with their headquarters. The first configuration, namely solutions $3\left(\sim \mathrm{BM}^{*} \mathrm{NR}^{*} \mathrm{BS}^{*} \sim \mathrm{IC}^{*} \sim \mathrm{MC}\right)$ with an empirical case of FDI5, represents a situation where institutional complexity is absent as a core condition while business modularization us absent as periphery conditions, and the firm does not need to consider market orientation, the firm can build dynamic capabilities to engage in localized learning only through reconfiguring firm resources (e.g., Teece et al., 1997), assets (e.g., know-how of business and highly specific knowledge) (Meyer et al., 2009), and its market competitiveness in local market (e.g., Jarillo \& Martinez, 1990). This situation is particularly relevant to FDI projects that Chinese MNEs have dominated competitive advantages in some specialized industries in host countries and their HQs can allow their foreign subsidiaries with a high autonomy, such as FDI5 made by MNE3. In 2006, MNE3 merged "the cornerstone of Australia's plastics industry" (that is, FDI5), which owns 70\% of the Australian plastics market. In this type of FDI, subsidiaries operate in a highly autonomous manner within a localized learning system, but do not need to consider much on the host country institutional complexity as local managers are more familiar with local institutional environment, and market orientation is not an important concern if the subsidiary still maintains its pre-M\&A market focus. For example, a local project director of FDI5 (an Australian manager) comments:
Our Beijing office (the HQ) implemented what they committed to us before the merging case - to remain an Australian company managed by Australians. When I met the Chairman and other managers in Beijing, I felt trust from them. Actually it is a smart way to manage this company [Australian subsidiary], because we know better about our local trade persons and the market as well. [AS5, FDI5]

In this situation, localized learning is motivated by some peripheral conditions. For example, localized learning may be motivated by specific mandatory business practices (such as the local occupational and health safety laws, human resource management rules, and workplace regulations etc.), which can be further strengthened by cultural distance. Local networks (e.g., managerial ties, industry associations and partnership with local firms and governments) may also motivate firms to learn more advanced production and managerial know-how locally.

The final configuration $\left(\mathbf{M O}^{*} \sim \mathbf{B M}^{*} \sim \mathbf{N R}^{*} \sim \mathbf{B S}^{*}\right.$ IC $^{*}$ MC; solution 4 with an empirical case of FDI11) implies that host market orientation is crucial towards being a locally responsive learner if the firm tends to ignore the importance of business modularization, network resources and business specificity. The finding supports the arguments made by Luo (2001), that is, the attention on the local responsiveness can vary because market demand and consumer behaviour are likely to differ according to region, income, gender, education, and other demographic attributes. Due to their daily management role, decision makers at the Australian subsidiary level, unlike their headquarters colleagues who are more likely to maintain a global vision, have a natural strategic focus on the local market conditions in the host country. Accordingly, the core condition market orientation and the two contributing conditions institutional complexity and market competition leading to localized learning at the subsidiary level, require the firm to not only adjust their strategic orientation towards local market conditions, but also understand institutional impact and market dynamics. For instance, the Australian subsidiary CEO of FDI11 point out:

We are operating a 'whole set equipment' or 'project-based' exporting business, so performance is important, not those bureaucratic things in this company. This type of business requires us to concentrate on learning market, and to be sensitive to local environment changes.

Of course, our strong international brand and our credit in international trade are also helpful for our localization. [AS11, FDI11]

This finding partially supports the viewpoints held by Fan et al. (2013), that Chinese managers can either focus on learning and dealing with the local institutional complexity or change their business practices to uniquely suit the local environment. Both of these alternative subsidiary management approaches will lead to high level of localized learning.

Comparing the results at the Australian subsidiary level with those at the headquarters level, it is evident that all of the core conditions are different across these two levels in motivating localized learning. Headquarters and subsidiaries are perceptive of the process-position-path configurations that drive localized learning, but at the same time the configurational determinants of localized learning demonstrate systematic difference between headquarters and subsidiary levels of EMNEs, which are generally consistent with Kostova and Roth's (2002) arguments. These differences between headquarters and subsidiaries support our Proposition 3. 


\subsection{Robustness tests}

We perform robustness checks to understand the stability of the configurational solutions. Following the suggestion of Crilly (2011), we replicated the analysis with a reduced consistency threshold of 0.80 . The combinations of core conditions remain in both parsimonious solutions and intermediate solutions, predicting the degree of localized learning. There is no change of results at the HQ level, except a minor reduced consistency level for Solution 1a from .87 to .86 . At the subsidiary level, the configurations are similar to those in the solution presented above, but they are less precise which is expected when applying a lower consistency threshold (cf. Crilly, 2011). Therefore, in line with Fiss (2011), our solutions with the consistency level at 0.869 for the HQ dataset and 0.880 for the Australian subsidiary dataset are preferred and reported in this study.

\section{Discussion and conclusion}

Adopting a configurational approach facilitated by fuzzy-set analytical technique, this study pioneers examination of the underlying process-position-path configurations influencing localized learning of EMNEs in developed host countries. Compared to the regression-based analyses of independent causal effect, this study employs the advantage of fsQCA to understand "the realities of strategizing" (Fiss, 2007: 1194) which often involves an interaction nexus of firm process, position and path factors, and equifinality of multiple pathways towards a final strategic outcome or behaviour. It thus contributes new insights into our understanding of EMNEs' knowledge acquisition effort through localized learning in FDI, by demonstrating causal configurations with core and peripheral conditions, and contrasting them at the headquarters and the subsidiary levels.

\subsection{Main findings}

Our fsQCA of eleven Chinese FDIs in Australia produced a number of key observations. Our core finding supports the equifinal configurational understanding of firm strategy. Strategy scholars contend that a firm's strategy needs to be interpreted in the context of an overall configuration of strategy that shapes, and is in turn shaped by, all of the firm's activities (Miller, 1996; Porter, 1996). Chetty and Campbell-Hunt (2003) further state that configurations of strategy arise as the result of inter-dependencies between firm activities, resources and assets. As localized learning is a strategic behaviour of particular importance for the internationalization success of EMNEs from a dynamic capability perspective, our findings show that such localized learning is motivated by a nexus of process-position-path factors, namely, market orientation, business modularization, network resources, business specificity, institutional complexity and market competition, working in configurations rather than in isolation. This finding suggests that decision makers can explore multiple combinations of process-position-path conditions that can lead to the same level of the desired localized learning outcome. In other words, the equifinality of causal conditions leading to the same learning emphasis is evident in the context of EMNEs operating in advanced host-countries.

This finding can potentially contribute to the internationalization process model (IPM). IPM centres on foreign market knowledge and the role of learning in a firm's internationalization (Hadjikhani, Hadjikhani, \& Thilenius, 2014; Johanson \& Vahlne, 2009). IPM literature has not provided a systematic explanation of the strategic variation between generalized and localized learning in firms' internationalization process. Our analysis reveals equifinal configurations of process-position-path factors that will motivate localized learning as opposed to generalized learning. We thus contribute to the advancement of IPM by explicating the antecedents of an important type of learning by internationalizing firms, namely localized learning.

Specifically, our findings show the roles of the different element of the process-position-path aspects of dynamic capabilities in motivating localized learning. Hadjikhani et al. (2014: 156) claim that "management of uncertainty involves the interplay between knowledge and market commitment and that experience-based learning and relationship building". Our findings in Solution 1a and $1 \mathrm{~b}$ (that is, FDI11 and FDI6) highlight the importance of localized learning when dealing with situations of some firms facing severe market competition in the host country. Compared with Johanson and Vahlne (2009), we further detailed how to drive the localized learning process in two specific scenarios. One is where managers observe institutional complexity without having abilities to utilize their network resources, and the other is the situation that managers can utilize their network resources without institutional complexity perception.

Following the steps of Japanese and Korean MNEs' successful international moves driven by strategic intent, many Chinese MNEs are actively, and sometimes aggressively, conducting asset seeking FDI (Luo \& Tung, 2007). In this strategically driven internationalization process, firms are often concerned not merely with the gains and losses from individual transactions but, more importantly, with building a strong position in the target markets (Chetty \& Campbell-Hunt, 2004; Luo \& Rui, 2009). Hence, learning to have a strong local network (including local governments and industry associations' support) is another option (see, our findings in Solution 2). The efforts of establishing local networks are more desirable and advantageous if Chinese MNEs are willing to overcome local trade barriers, host country regulatory uncertainty (e.g., Haley \& Schuler, 2011), and achieve managerial efficiency (e.g., cost reduction and resource dependence). This learning orientation is also reflected in the observation of business modularization being constantly absent, which can be explained in two ways. On one hand, it suggests that most Chinese MNEs focus on strategic asset seeking when investing in developed host countries. As such, their decision makers' mind-sets are dominated by exploratory thinking that implies firm behaviours characterized by search, discovery, experimentation, risk taking and innovation; rather than exploitative orientation that implies firm behaviours characterized by refinement, implementation, efficiency, production and selection (He \& Wong, 2004). On the other hand, absence of business modularization may be due to the location advantage of developed host countries embedded in their macro-economic structure, which provide EMNEs with unique learning opportunities. For instance, the Australian economy advances both resource and service sectors, but not in the manufacturing sector. Therefore, business modularization might not be a realistic option for many Chinese managers (see, our findings in Solutions 3 and 4).

Apart from supporting the configurational equifinality approach to strategy in general and to EMNE localized learning in specific (Proposition 1), our findings also demonstrate the varying roles of causal conditions in the configurational approach (Proposition 2), as well as the perception gap between organizational decision makers that leads to the distinction of configurational solutions between decision makers (Proposition 3). Regarding Proposition 2, our analysis supports the proposition that the process-position-path configurations of localized learning determinants are characterized by a core and a periphery. We find that strategic decision makers do not place equal emphasis on configurational elements when dealing with the challenge of being a local responsive learner. A number of scholars (e.g., Fiss, 2011; 
Romanelli \& Tushman, 1994; Siggelkow, 2002) claim that it is necessary to develop a better understanding of the nature of core elements in configurational theory because core elements are most important to specific strategic outcomes. Specific to EMNEs' localized learning, the core conditions in the causal configurations include local market competition, non-business specificity, demand heterogeneity, and market orientation, at both headquarters and subsidiary levels, while other factors play a peripheral role. The core-periphery distinction revealed in this study suggests the existence of a trade-off between these key elements when decision makers are faced with localized learning challenges.

With regard to Proposition 3, the process-position-path elements of localized learning are markedly different between senior executives at the headquarters and the subsidiary levels of Chinese MNEs. The qualitative evidence not only highlights that the methodological importance of distinguishing the level of analysis conducted, but also demonstrates the 'perception gap' of strategic decision makers highlighted by Chini, Ambos, \& Wehle (2005). Chini et al. (2005) emphasizes that identifying perception gaps within organizations is important because it may lead to dysfunctional tension or performance misjudgement in the MNE. Perception gap leads to different interpretation of environment and preference for strategy, both across functional units of a firm (Birkinshaw, Holm, Thilenius, \& Arvidsson, 2000; Brockhoff, 1998), and between levels of corporate actors such as managers and workers. In terms of motivating localized learning, our findings demonstrate clear distinction between the decision factors emphasized by headquarters managers and those emphasized by subsidiary managers, as none of the core conditions in any configurational solutions repeats itself at both headquarters and subsidiary levels. This finding suggests that diverging strategic mind-sets exist at the headquarters and subsidiary levels of EMNEs, and such divergence may create tension in the implementation of localized learning in their internationalization process. While this study does not address the tension and its strategic implication per se, it reveals strategic perception gas as the source of the tension.

\subsection{Theoretical implications}

This study makes several contributions to the literature. By examining localized learning in developed host countries, this study adds to the understanding of the learning activities involved in the internationalization process of EMNEs, a strategic element differentiating them from developed country multinationals (Luo \& Tung, 2007). Therefore this study contributes to the EMNE literature.

We demonstrate how the dynamic capability framework can inform the study of EMNEs and thus add to the theoretical repertoire of international business research (Teece, 2014). We find equifinal configurations of process-position-path conditions of dynamic capabilities motivate localized learning by EMNEs. Thus, we show that this overarching framework is particularly useful for understanding the internationalization process of ENMEs, given their strategic emphasis on learning and capability building. While EMNEs may not possess strong dynamic capabilities that sustain global competitiveness at the current stage of their development, the conditions forming their dynamic capabilities will motivate them to engage in learning activities that will help them enhance their core-competencies and build global competitiveness in the long term. In this sense, both developed MNEs and EMNEs face competitive pressures of upgrading their core competencies, but for different purposes (sustaining or building competitive advantages) and through different ways (global synergizing or localized learning). Therefore dynamic capabilities play important role in explaining the strategic behaviours of developed MNEs and EMNEs.

Also we combine the dynamic capability framework with a configurational approach of theory building to explore the equifinal pathways that involves multiple factor interactions in firms' strategy formulation and implementation. Existing studies on EMNE internationalization strategy have typically adopted a contingency approach (e.g., Hu \& Cui, 2014; Lu, Liu, Wright, \& Filatotchev, 2014), while configurations that involves higher levels of interactions have not been empirically studied (Jormanainen \& Koveshnikov, 2012). Nonetheless firms often make important strategic decisions while considering a nexus of process-position-path factors in interaction with each other, and a given strategy may serve multiple situations. We demonstrate how the fsQCA technique can be utilized to address this limitation and facilitate future advancement of the literature.

When dealing with causal complexity that is perhaps the most common form of causality facing a firm's decision makers, traditional contingency theorists proposed a fundamental assumption that there exists no universal best way to organize, and that any given way of organizing is not equally effective under all conditions (Galbraith, 1973). The assumption can be extended to the strategy context, that is, the field of business policy exemplified by the initial strategy paradigm is rooted in the concept of matching organizational features with the corresponding environmental context (Andrews, 1980; Ginsberg \& Venkatraman, 1985). Ginsberg and Venkatraman (1985) further affirm that without considering the organization's resource positions and environmental path, a universal set of strategic choices does not exist. Accordingly, a core issue in the contingency approach of strategy is to identify what constitutes fit. However identifying a fit has not been well solved by analysts, especially when in a situation where multiple contingencies may present the firm with contradictory requirements for strategy (e.g., Donaldson, 2001; Miller, 1992). Then it results in a trade-off requirement between multiple and differing demands. Yet, discovering such a trade-off among strategic decision makers' mind-sets is arguably at the core of strategy research and has led scholars to call for a new methodology that takes into account configurational patterns, equifinality and multiple contingencies (Donaldson, 2001; Fiss, 2007; Greckhamer, Misangyi, Elms, \& Lacey, 2008).

This study applies a set-theoretical approach to study the strategic behaviours of EMNEs in their internationalization, and capture how process-position-path factors combine rather than compete to produce an outcome. Fiss (2007) and Ragin (2008) argue that a set-theoretical approach is much more closely aligned with the theoretical thrust of configurational theory, which suggests a clean break with the predominant linear paradigm based on contingency perspective. Rather than implying singular causation and linear relationships, the configurational perspective assumes complex causality and nonlinear relationships where "variables found to be causally related in one configuration may be unrelated or even inversely related in another" (Meyer et al., 1993: 1178). As a result, relationships between variables/factors need not be symmetric (Black \& Boal, 1994) and tend to involve synergistic effects that go beyond traditional bivariate interaction effects (Fiss, 2007). Moreover, unlike contingency perspective which emphasizes the unifinality, configurational perspective stresses the concept of "equifinality", which refers to a situation where "a system can reach the same final state, from different initial conditions and by a variety of different paths" (Katz \& Kahn, 1978: 30). While unifinality assumes the existence of one optimal configuration, equifinality assumes that two or more 
organizational configurations can be equally effective in achieving the same strategic target, even if they are faced with the same contingencies (Gresov \& Drazin, 1997). By applying this set-theoretical approach, we bring configurational theory to the study of EMNE internationalization, which often presents complex decision tasks that involves a nexus of internal and external factors in constant interaction and trade-off with each other. This set-theoretical approach has emerged as a powerful tool to advance understanding of strategic management issues (Fiss, 2007, 2009), and is increasingly appreciated by international business researchers (Crilly, 2011; Schneider et al., 2010).

\subsection{Managerial implications}

Our findings offer practical implications for EMNEs. We echo the importance of network resources in supporting localized learning (cf. Johanson \& Vahlne, 2009). In terms of practice, EMNEs with pre-established global linkage, either through inward internationalization at home or by contractual or export-based prior internationalization, are more likely to engage in localized learning when conducting FDI in developed host countries. Moreover, the Uppsala internationalization process model holds that firms need to place emphasis on obtaining market-specific business knowledge in order to avoid "the liability of outsidership" (Johanson \& Vahlne, 2009: 1416). The study also suggests that EMNEs should stress their market know-how, which would significantly drive their localized learning behaviour, especially in a situation of intensive market competition that requires clear market orientation when the firm does not have specialized business practices (in other orders, producer knowledge). Likewise, some local factors in the host countries can motivate localized learning. Apart from local network building and local market competition, institutional complexity signals the need for localized learning. EMNEs need to carefully assess the host country's local condition, especially when they tend to leapfrog into culturally, economically, and institutionally distanced locations rather than following a gradual internationalization path (Luo \& Tung, 2007).

Furthermore, market orientation supports localized learning in majority of the cases other than FDI purely for natural resource seeking. The implication is that EMNEs that have accumulated sufficient marketing capabilities at home are more likely to be successful localized learners when investing in developed host countries. This is particularly important for state-controlled firms who have inherent disadvantages in a market driven environment, and therefore need to invest in developing such capabilities before venturing overseas.

Last but not least, the potential tension between headquarters and subsidiaries with regard to localized learning need to be acknowledged and discussed in order to reach a coherent knowledge acquisition strategy of EMNEs. It is important for headquarters to understand and support the localized learning by subsidiaries, even when such a motivation is not necessarily present at the headquarters level. This is because localized learning occurs at the subsidiary level first; and without it, reverse knowledge transfer at the corporate level will not be possible (Erramilli, 1991; Luo \& Peng, 1999). In other words, the corporate level strategic visions of EMNEs must be supported by subsidiary level initiatives.

\subsection{Limitations and future research}

Some limitations of the study need to be acknowledged, which also indicate some possible future research directions. First, while we drew on existing literature to capture a wide range of firm-environmental factors that may affect localized learning, this coverage may still be incomplete. Factors, such as local trade barriers, local business infrastructure, resource dependence and regional headquarters' role might have an impact on localized learning. Future study can conduct analyses on these factors as an extension to the current study. Due to economic and political dynamics, there might be new factors affecting localized learning, which need to be informed by exploratory studies in the future.

Second, a cross-level research design in this study only involves Chinese MNEs headquarters and their Australian subsidiaries. Future research can expand the configurational comparison not only across MNE hierarchies (vertical levels), but also between localities (horizontal levels). For example, subsidiaries located in different host countries may engage in localized learning for different motives. A comparison at both vertical and horizontal levels can present a more comprehensive understanding of the global business network of an MNE, and its overall internationalization strategy. Research in this direction also allows investigation of potential localized learning of EMNEs in other emerging economies, which is likely to be driven by different motives than their learning from developed host countries.

Third, the study sacrifices the sample size for matching a crosslevel design in eleven Chinese FDI projects in Australia. As mentioned in the method section, the small sample size with six casual conditions has the limited diversity ( $2^{k}$ possibility) issue as 11 case FDI at either HQs or Australian subsidiary level cannot cover all $2^{6}$ logical possibilities (e.g., Berg-Schlosser \& De Meur, 2009). Although the limited diversity is tolerated in the literature (cf. Crilly, 2011; Fiss, 2011; Hotho, 2014), the future study can enlarge the sample size to test of the generalizability of our findings. In addition, the majority of case organizations in this study are large state-owned firms dominant within their industries. Future studies might attempt to enlarge the sample size at a single level but involve more multinationals that are privately owned and/or small and medium in size. Their inclusion could not only improve our understanding of organizational factors and managers' perceptions across more multinationals in regard to both environmental factors, and their foreignness in overseas markets, but also test the robustness of our findings in multinational contexts.

\section{Acknowledgements}

We thank three anonymous reviewers and IBR guest editor Professor Xiaohui Liu for their constructive comments on earlier versions of this paper. Our thanks also go to Professor Charles Ragin for his patience, encouragement and insightful guidance on the methodology. The first author thanks financial support of Victoria University (RDGS 22-12) and Deakin University (CRGS RM\#: 27645). The second author thanks research support from the Australian Research Council (DE130100860) and the National Natural Science Foundation of China (71472038). 


\section{Appendix A. Extract of interview protocol for senior executives}

Generalized learning vs. Localized learning

1. As an MNE, do you think which one is more important between generalized learning and localized learning? And Why?

2. Based on the consideration of your corporation's current situations, which one is the dominant aspect?

3. a) If you prefer to change you MNE to be more generalized learning, what factors do you most consider? Could you please describe / list them?

b) If you prefer to change you MNE to be more localized learning, what factors do you most consider? Could you please describe / list them?

4. The literature states there are four international business strategies:

i. International strategy (Low Integration (I); Low Responsiveness (R));

ii. Global Strategy (High H; Low R);

iii. Multi-domestic strategy (Low I; High R);

iv. Transnational strategy (High I; High R)

a) Which one of the above four strategies can best describe your corporation current situation?

b) If you will be the decision maker for making such strategies, which one do you prefer?

Dynamic Capabilities

5. Could you please describe the overall internationalization process of your corporation? Why are you interested in investing in Australia?

6. What kind of resources do you own for assisting you on investing in Australia? Do you think this specific resource can facilitate your FDI project in Australia or gain overall comparative advantages for your corporation?

7. Do you have any business strategies that guide your FDI project in Australia?

\section{Casual Conditions}

8. a) In terms of localized learning based on your foreign direct investment (FDI) in Australia, how do you rank market orientation as a factor that has impact on the localized learning (e.g strong vs. weak, more vs. less)?

b) Could you please also explain why you think this factor is important or not important?

... Repeat the question style for the following factors...

such as, business modularization, network resources (e.g. governmental supports), business specificity, institutional complexity, market competition.

\section{References}

Anderson, E., \& Coughlan, A. T. (1987). International market entry and expansion via independent or integrated channels of distribution. Journal of Marketing, 51(1), 71-82.

Andrews, K. R. (1980). The concept of corporate strategy. Irwin: Homewood, IL.

Barney, J. (1991). Firm resources and sustained competitive advantage. Journal of Management, 17(1), 99-120.

Barr, P. S., Stimpert, J. L., \& Huff, A. S. (1992). Cognitive change, strategic action, and organizational renewal. Strategic Management Journal, 13(S1), 15-36.

Barreto, I. (2010). Dynamic capabilities: A review of past research and an agenda for the future. Journal of Management, 36(1), 256-280.

Bartlett, C. A., \& Ghoshal, S. (1998). Managing across borders: The transnational solution (2nd ed.). Boston: Harvard Business School Press.

Basurto, X. (2013). Linking multi-level governance to local common-pool resource theory using fuzzy-set qualitative comparative analysis: Insights from twenty years of biodiversity conservation in Costa Rica. Global Environmental Change, 23(3), 573-587.

Basurto, X., \& Speer, J. (2012). Structuring the calibration of qualitative data as sets for qualitative comparative analysis (QCA). Field Methods, 24(2), 155-174.

Berg-Schlosser, D., \& De Meur, G. (2009). Comparative research design: Case and variable selection. In B. Rihoux \& C. C. Ragin (Eds.), Configurational comparative methods: Qualitative comparative analysis (QCA) and related techniques (pp. 19-33). Sage: Thousand Oaks.

Birkinshaw, J. (1996). How multinational subsidiary mandates are gained and lost. Journal of International Business Studies, 27(3), 467-495.

Birkinshaw, J. M., \& Morrison, A. J. (1995). Configurations of strategy and structure in subsidiaries of multinational corporations. Journal of International Business Studies, 26(4), 729-753.

Birkinshaw, J., Holm, U., Thilenius, P., \& Arvidsson, N. (2000). Consequences of perceptions gaps in the headquarters - Subsidiary relationship. International Business Review, 9(3), 321-344.

Black, J. A., \& Boal, K. B. (1994). Strategic resources: Traits, configurations and paths to sustainable competitive advantage. Strategic Management Journal, 15(S2), 131-148.

Boddewyn, J., \& Brewer, T. L. (1994). International business political behavior: New theoretical direction. Academy of Management Journal, 19(1), 119-143.

Boisot, M., \& Child, J. (1999). Organizations as adaptive systems in complex environments: The case of China. Organization Science, 10(3), 237-252.

Brockhoff, K. (1998). Internationalization of research and development. Berlin: Springer.
Burt, R. S. (1997). The contingent value of social capital. Administrative Science Quarterly, 42(2), 339-365.

CCCA (China Chamber of Commerce in Australia) (2009). The Commercial Relations between China and Australia. Sydney: China Chamber of Commerce in Australia Retrieved from http://www.ccpitaus.org/aboutccca/ccca_en.html (27.01.10).

Chan, C. M., \& Makino, S. (2007). Legitimacy and multi-level institutional environments: Implications for foreign subsidiary ownership structure. Journal of International Business Studies, 38(4), 621-638.

Chang, S. J. (1995). International expansion strategy of Japanese firms: Capability building through sequential entry. Academy of Management Journal, 38(2), 383407.

Chetty, S., \& Campbell-Hunt, C. (2003). Paths to internationalisation among small- to medium-sized firms: A global versus regional approach. European Journal of Marketing, 37(5/6), 796-820.

Chetty, S., \& Campbell-Hunt, C. (2004). A strategic approach to internationalization: A traditional versus a born-global. Journal of International Management, 12(1), $57-81$

Chini, T., Ambos, B., \& Wehle, K. (2005). The headquarters-subsidiaries trench: Tracing perception gaps within the multinational corporation. European Management Journal, 23(2), 145-153.

Collis, D. J. (1991). A resource-based analysis of global competition: The case of the bearings industry. Strategic Management Journal, 12(1), 49-68.

Crilly, D. (2011). Predicting stakeholder orientation in the multinational enterprise: A mid-range theory. Journal of International Business Studies, 42(5), 694-717.

Crilly, D., Zollo, M., \& Hansen, M. (2012). Faking it or muddling through? Understanding decoupling in response to stakeholder pressures. Academy of Management Journal, 55(6), 1429-1448.

Cui, L., \& Jiang, F. (2009). FDI entry mode choice of Chinese MNCs: A strategic behaviour perspective. Journal of World Business, 44(4), 434-444

Cui, L., Meyer, K. E., \& Hu, H. W. (2014). What drives firms' intent to seek strategic assets by foreign direct investment? A study of emerging economy firms. Journal of World Business. http://dx.doi.org/10.1016/j.jwb.2013.12.003

Donaldson, L. (2001). The contingency theory of organizations. Thousand Oaks: Sage Publications

Doty, D. H., \& Glick, W. H. (1994). Typologies as a unique form of theory building: Toward improved understanding and modeling. Academy of Management Review, 19(2), 230-251.

Drnevich, P. L., \& Kriauciunas, A. P. (2011). Clarifying the conditions and limits of the contributions of ordinary and dynamic capabilities to relative firm performance. Strategic Management Journal, 32(3), 254-279. 
Dunning, J. H. (1981). International production and the multinational enterprise. London: Allen and Unwin.

Eberhardt, M., McLaren, J., Millington, A., \& Wilkinson, B. (2004). Multiple forces in component localisation in China. European Management Journal, 22(3), 290-303.

Economist Intelligence Unit (2010). A brave new world: The climate for Chinese ME'A abroad. The Economist. Retrieved from http://www.eiu.com/site_info. asp?info_name=eiu_The_climate_for_Chinese_MandA_abroad\&rf=0 (12.11.10).

Elango, B., \& Pattnaik, C. (2007). Building capabilities for international operations through networks: A study of Indian firms. Journal of International Business Studies, 38(4), 541-555.

Eriksson, K., Johanson, J., Majkgard, A., \& Sharma, D. D. (1997). Experiential knowledge and cost in the internationalization process. Journal of International Business Studies, 28(2), 337-360.

Ernst, R., \& Kamrad, B. (2000). Evaluation of supply chain structures through modularization and postponement. European Journal of Operational Research, 124(3), 495-510.

Erramilli, M. K. (1991). The experience factor in foreign market entry behavior of service firms. Journal of International Business Studies, 22(3), 459-502.

Ezell, S. J., Atkinson, R. D., \& Wein, M. A. (2013). Localization barriers to trade: Threat to the global innovation economy. Washington, DC: The Informational Technology \& Innovation Foundation.

Fan, D., Zhu, C. J., \& Nyland, C. (2012). Factors affecting global integration of Chinese multinationals in Australia: A qualitative analysis. International Business Review, 21(1), 13-26.

Fan, D., Zhang, M., \& Zhu, C. J. (2013). International human resource management strategies of Chinese multinationals operating abroad. Asia Pacific Business Review, 19(4), 526-541.

FIRB (Foreign Investment Review Board) (2012). Foreign investment review board annual report 2011-2012. Canberra, Australia.

Fiss, P. C. (2007). A set-theoretic approach to organisational configurations. Academy of Management Review, 32(4), 1180-1198.

Fiss, P. C. (2009). Case studies and the configurational analysis of organizational phenomena. In C. Ragin \& D. Byrne (Eds.), Handbook of case study methods (pp. 424-440). Thousand Oaks, CA: Sage.

Fiss, P. C. (2011). Building better causal theories: A fuzzy set approach to typologies in organisation research. Academy of Management Journal, 54(2), 393-420.

Galbraith, J. (1973). Designing complex organizations. Reading, MA: Addison-Wesley.

Gao, L., Liu, X., \& Zou, H. (2013). The role of human mobility in promoting Chinese outward FDI: A neglected factor? International Business Review, 22(2), 437-449.

Ghoshal, S. (1987). Global strategy: An organizing framework. Strategic Management Journal, 8(5), 425-440.

Ghoshal, S., \& Nohria, N. (1989). Internal differentiation within multinational corporations. Strategic Management Journal, 10(4), 323-337.

Ginsberg, A., \& Venkatraman, N. (1985). Contingency perspectives of organizational strategy: A critical review of the empirical research. Academy of Management Review, 10(3), 421-434.

Grandori, A., \& Furnari, S. (2008). A chemistry of organizations: Combinatory analysis and design. Organization Studies, 29(3), 459-485.

Granovetter, M. (1995). Coase revisited: Business groups in the modern economy. Industrial and Corporate Change, 4(1), 93-130.

Greckhamer, T., Misangyi, V. F., Elms, H., \& Lacey, R. (2008). Using qualitative comparative analysis in strategic management research: An examination of combinations of industry, corporate, and business-unit effects. Organizational Research Methods, 11(4), 695-726.

Grein, A. F., Craig, C. S., \& Takada, H. (2001). Integration and responsiveness: Marketing strategies of Japanese and European automobile manufacturers. Journal of International Marketing, 9(2), 19-50.

Gresov, C., \& Drazin, R. (1997). Equifinality: Functional equivalence in organization design. Academy of Management Review, 22(2), 403-428.

Gupta, A. K., \& Govindarajan, V. (1991). Knowledge flows and the structure of control within multinational corporations. Academy of Management Review, 16(4), 768-792.

Hadjikhani, A., Hadjikhani, A. I., \& Thilenius, P. (2014). The internationalization process model: A proposed view of firms' regular incremental and irregular non-incremental behaviour. International Business Review, 23(2), 155-168.

Haley, U. C. V., \& Haley, G. T. (2013). Subsidies to Chinese industry: State capitalism, business strategy, and trade policy. Oxford, London: Oxford University Press.

Haley, U. C. V., \& Schuler, D. A. (2011). Government policy and firm strategy in the solar photovoltaics industry. California Management Review, 54(1), 17-38.

He, Z. L., \& Wong, P. K. (2004). Exploration vs. exploitation: An empirical test of the ambidexterity hypothesis. Organization Science, 15(4), 481-494.

Hotho, J. J. (2014). From typology to taxonomy: A configurational analysis of national business systems and their explanatory power. Organization Studies, 35(5), $671-702$.

Hu, H. W., \& Cui, L. (2014). Outward foreign direct investment of publicly listed firms from China: A corporate governance perspective. International Business Review, 23(4), 750-760. http://dx.doi.org/10.1016/j.ibusrev.2013.11.003

Ichijo, K., \& Kohlbacher, F. (2008). Tapping tacit local knowledge in emerging markets The Toyota way. Knowledge Management Research \& Practice, 6(3), 173-186.

Jarillo, J. C., \& Martinez, J. I. (1990). Different roles for subsidiaries: The case of multinational corporations in Spain. Strategic Management Journal, 11(7), 501-512.

Johanson, J., \& Vahlne, J. (1977). The internationlization process of the firm - A model of knowledge development and increasing foreign market commitment. Journal of International Business Studies, 8(1), 23-32.

Johanson, J., \& Vahlne, J.-E. (1990). The mechanism of internationalisation. International Marketing Review, 7(4), 11-24.
Johanson, J., \& Vahlne, J.-E. (2009). The Uppsala internationalization process model revisited: From liability of foreignness to liability of outsidership. Journal of International Business Studies, 40(9), 1411-1431.

Jormanainen, I., \& Koveshnikov, A. (2012). International activities of emerging market firms: A critical assessment of research in top international management journals. Management International Review, 52(5.), 691-725.

Judge, W. Q., Fainshmidt, S., \& Brown, J. L., III (2014). Which model of capitalism best delivers both wealth and equality? Journal of International Business Studies, 45(3), 363-386.

Katz, D., \& Kahn, R. L. (1978). The social psychology of organizations (2nd ed.). New York: Wiley.

Kostova, T., \& Roth, K. (2002). Adoption of an organizational practice by subsidiaries of multinational corporations: Institutional and relational effects. Academy of Management Journal, 45(1), 215-233.

KPMG (2013). Demystifying Chinese investment in Australia. Sydney: KPMG International

Li, Y., Li, L., Liu, Y., \& Wang, L. (2005). Linking management control system with product development and process decisions to cope with environment complexity. International Journal of Production Research, 43(12), 2577-2591.

Lin, W. T., Cheng, K. Y., \& Liu, Y. S. (2009). Organizational slack and firm's internationalization: A longitudinal study of high-technology firms. Journal of World Business, 44(4), 397-406

Liu, X., \& Buck, T. (2009). The internationalisation strategies of Chinese firms: Lenovo and BOE. Journal of Chinese Economic and Business Studies, 7(2), 167-181.

Lu, J., Liu, X., Wright, M., \& Filatotchev, I. (2014). International experience and FDI location choices of Chinese firms: The moderating effects of home country government support and host country institutions. Journal of International Business Studies. http://dx.doi.org/10.1057/jibs.2013.68

Luo, Y. (2001). Determinants of local responsiveness: Perspectives from foreign subsidiaries in an emerging market. Journal of Management, 27(4), 451-477.

Luo, Y. (2002). Organizational dynamics and global integration: A perspective from subsidiary managers. Journal of International Management, 8(2), 189-215.

Luo, Y. (2003). Industrial dynamics and managerial networking in an emerging market: The case of China. Strategic Management Journal, 24(13), 1315-1327.

Luo, Y., \& Peng, M. W. (1999). Learning to compete in a transition economy: Experience environment, and performance. Journal of International Business Studies, 30(2), 269-295.

Luo, Y., \& Rui, H. (2009). An ambidexterity perspective toward multinational enterprises from emerging economies. Academy of Management Perspectives, 23(4), 49-70.

Luo, Y., \& Tung, R. L. (2007). International expansion of emerging market enterprises: A springboard perspective. Journal of International Business Studies, 38(4), 481-498.

Lyles, M., Li, D., \& Yan, H. (2014). Chinese outward FDI performance: The role of learning. Management and Organization Review. http://dx.doi.org/10.1111/ more.12056

Metelits, C. M. (2009). The consequences of rivalry: Explaining insurgent violence using fuzzy sets. Political Research Quarterly, 62(4), 673-684.

Meyer, A. D., Tsui, A. S., \& Hinings, C. R. (1993). Configurational approaches to organizational analysis. Academy of Management Journal, 36(6), 1175-1195.

Meyer, K. E., Wright, M., \& Pruthi, S. (2009). Managing knowledge in foreign entry strategies: A resource-based analysis. Strategic Management Journal, 31(5), $557-574$

Miles, R. E., Snow, C. C., Meyer, A. D., \& Coleman, H. J., Jr. (1978). Organizational strategy, structure, and process. Academy of Management Review, 3(3), 546-562.

Miller, D. (1986). Configurations of strategy and structure: Towards a synthesis. Strategic Management Journal, 7(3), 233-249.

Miller, K. D. (1992). A framework for integrated risk management in international business. Journal of International Business Studies, 23(2), 311-331.

Miller, D. (1996). Configurations revisited. Strategic Management Journal, 17(7), 505-512.

MOFCOM (Ministry of Commerce People's Republic of China) (2012). 2012 Statistical bulletin of China's outward foreign direct investment. Beijing: China Statistics Press.

Morck, R., Yeung, B., \& Zhao, M. (2008). Perspectives on China's outward foreign direct investment. Journal of International Business Studies, 39(3), 337-350.

Nadkarni, S., \& Narayanan, V. K. (2007). The evolution of collective strategy frames in high- and low-velocity industries. Organization Science, 18(4), 688-710.

Narver, J., \& Slater, S. (1990). The effect of a market orientation on business profitability. Journal of Marketing, 54(4), 20-35

Nyland, C., Forbes-Mewett, H., \& Thomson, S. (2011). Sinophobia as corporate tactic and the response of host communities. Journal of Contemporary Asia $41(4), 610-631$

Pajunen, K. (2008). Institutions and inflows of foreign direct investment: A fuzzy-set analysis. Journal of International Business Studies, 39(4), 652-669.

Porter, M. E. (1990). The competitive advantage of nations. Harvard Business Review 68(2), 73-93

Porter, M. E. (1996). What is strategy? Harvard Business Review, 74(6), 61-78.

Prahalad, C. K. (1975). The strategic process in a multinational corporation (Unpublished doctoral dissertation) Boston: Harvard Business School.

Ragin, C. (2008). Redesigning social inquiry: Fuzzy sets and beyond. Chicago, USA University of Chicago Press

Ragin, C. C., \& Fiss, P. C. (2008). Net effects analysis versus configurational analysis: An empirical demonstration. In C. C. Ragin (Ed.), Redesigning social inquiry: Fuzzy sets and beyond (pp. 190-212). Chicago, USA: University of Chicago Press.

Ramamurti, R., \& Singh, J. V. (Eds.). (2009). Emerging multinationals from emerging markets. Cambridge, UK/New York: Cambridge University Press.

Romanelli, E., \& Tushman, M. L. (1994). Organizational transformation as punctuated equilibrium: An empirical test. Academy of Management Journal, 37(5), 1141-1166. 
Root, F. R. (1988). Environmental risks and the bargaining power of multinational corporations. International Trade Journal, 3(1), 112-124.

Rugman, A. M., \& Li, J. (2007). Will China's multinationals succeed globally or regionally? European Management Journal, 25(5), 333-343.

Rui, H., \& Yip, G. S. (2008). Foreign acquisitions by Chinese firms: A strategic intent perspective. Journal of World Business, 43(2), 213-226.

Schneider, M. R., Schulze-Bentrop, C., \& Paunescu (2010). Mapping the institutiona capital of high-tech firms: A fuzzy-set analysis of capitalist variety and export performance. Journal of International Business Studies, 41(2), 246-266.

Siggelkow, N. (2002). Evolution towards fit. Administrative Science Quarterly, 47(1), 25-159.

Slater, S. F., \& Narver, J. C. (1995). Market orientation and the learning organization. Journal of Marketing, 59(3), 63-74.

Starr, M. K. (1965). Modular-production: A new concept. Harvard Business Review, 43(6), 131-142.

Su, C., Mitchell, R. K., \& Sirgy, M. J. (2007). Enabling guanxi management in China: A hierarchical stakeholder model of effective guanxi. Journal of Business Ethics, 71(3), 301-319.

Swamidass, P. M., \& Kotabe, M. (1993). Component sourcing strategies of multinationals: An empirical study of European and Japanese multinationals. Journal of International Business Studies, 24(1), 81-99.

Taggart, J. (1997). An evaluation of the integration-responsiveness framework: MNC manufacturing subsidiaries in the UK. Management International Review, 37(4), $295-318$.
Tallman, S. B. (1991). Strategic management models and resource-based strategies among MNEs in a host market. Strategic Management Journal, 12(1), 69-82.

Tan, D., \& Meyer, K. E. (2010). Business groups' outward FDI: A managerial resource perspective. Journal of International Management, 16(2), 154-164.

Teece, D. J. (2014). A dynamic capabilities-based entrepreneurial theory of the multinational enterprise. Journal of International Business Studies, 45(1), 8-37.

Teece, D. J., Pisano, G., \& Shuen, A. (1997). Dynamic capabilities and strategic management. Strategic Management Journal, 18(7), 509-533.

West, M. A., \& Anderson, N. R. (1996). Innovation in top management teams. Journal of Applied Psychology, 81(6), 680.

Xu, D., \& Shenkar, O. (2002). Institutional distance and the multinational enterprise. Academy of Management Review, 27(4), 608-618.

Zaheer, S. (1995). Overcoming the liability of foreignness. Academy of Management Journal, 38(2), 341-363.

Zaheer, S. (2002). The liability of foreignness, redux: A commentary. Journal of International Management, 8(3), 351-358.

Zhang, M., \& Fan, D. (2014). Expatriate skills training strategies of Chinese multinationals operating in Australia? Asia Pacific Journal of Human Resources, 52(1), 60-76.

Zhang, H. Y., \& Van Den Bulcke, D. (1996). China: Rapid changes in the investment development path. In J. H. Dunning \& R. Narula (Eds.), Foreign direct investment and governments: Catalysts for economic restructuring. London: Routledge.

Zhou, L. X., Barnes, B. R., \& Lu, Y. A. (2010). Entrepreneurial proclivity, capability upgrading and performance advantage of newness among international new ventures. Journal of International Business Studies, 41(5), 882-905. 